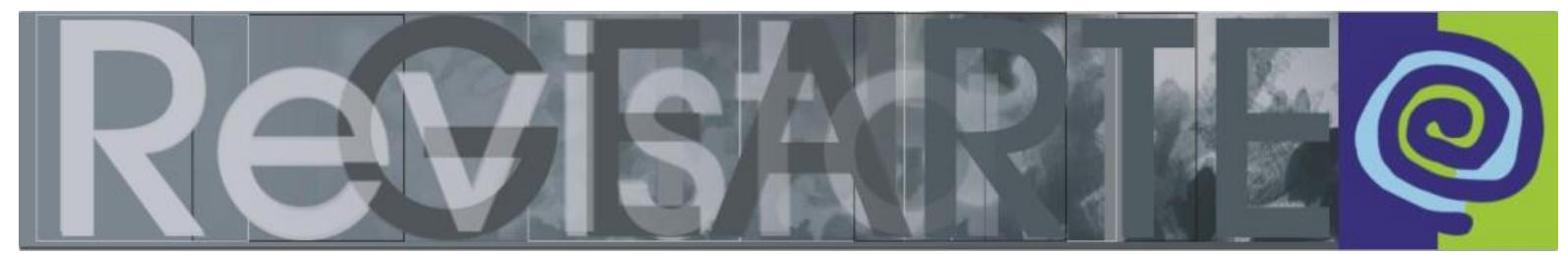

ISSN 2357-9854 | e-ISSN 2596-3198 (online)

\title{
Anita, Mário e a modernidade da arte/educação brasileira
}

\author{
Rejane Galvão Coutinho \\ (Universidade Estadual Paulista Júlio de Mesquita — UNESP, São Paulo/SP, Brasil)
}

\begin{abstract}
RESUMO - Anita, Mário e a modernidade da arte/educação brasileira - $O$ artigo ressalta as contribuições de Anita Malfatti e Mário de Andrade para a modernidade da arte/educação brasileira, colocando em evidência o plano de curso de desenho para crianças deixado por Anita, que é comentado e posto em relação com a coleção de desenhos infantis de Mário de Andrade. Trata-se de uma livre interpretação de parte da história do ensino de artes no Brasil tendo como referências principais as pesquisas de Ana Mae Barbosa e Marta Rossetti Batista.
\end{abstract}

PALAVRAS-CHAVE

Anita Malfatti. Professora/artista. Mário de Andrade. Ensino de desenho. História do ensino de artes.

RESUMEN - Anita, Mário y la modernidad del arte/educación brasileña - El artículo destaca las contribuciones de Anita Malfatti y Mário de Andrade a la modernidad del arte/educación brasileña, destacando el plan de curso de dibujo para niños dejado por Anita, que se comenta y se relaciona con la colección de dibujos infantiles de Mário de Andrade. Es una interpretación libre de parte de la historia de la educación artística en Brasil, teniendo como principales referencias la investigación de Ana Mae Barbosa y Marta Rossetti Batista.

\section{PALABRAS CLAVE}

Anita Malfatti. Profesora/artista. Mário de Andrade. Enseñanza de dibujo. Historia de la educación artística.

ABSTRACT - Anita, Mário and the modernity of Brazilian art/education - The article highlights the contributions of Anita Malfatti and Mário de Andrade for the modernity of Brazilian art / education, highlighting the drawing course plan for children left by Anita, which is commented on and related to the collection of children's drawings by Mário de Andrade. It is a free interpretation of part of the history of art education in Brazil, having as main references the research by Ana Mae Barbosa and Marta Rossetti Batista.

KEYWORDS

Anita Malfatti. Teacher/artist. Mário de Andrade. Drawing teaching. History of art education.

Como é bom, Anita, a gente separar-se, assim, por umas horas, da caravana. Abandonar trabalhos e preocupações, abandonar a própria felicidade que a todos abraça num ou noutro instante, para viver este limbo de lazer em que estamos agora...

Mário de Andrade ${ }^{1}$

Tomo aqui de empréstimo as palavras de Mário de Andrade para convidar as leitoras e os leitores a abandonar um pouco a caravana e as preocupações,

1 ANDRADE, Mário de. No Atelier. In: _. Mário de Andrade, cartas a Anita Malfatti. Organização de Marta Rossetti Batista. Rio de Janeiro: Forense Universitária, 1989, p. 45. 


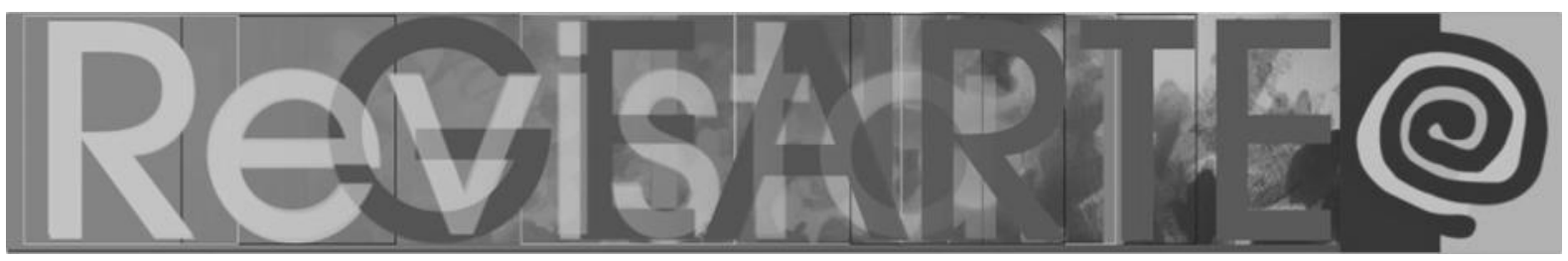

abrindo espaço no limbo de nossos dias para compartilhar este passeio na história da arte/educação.

A citação acima faz parte de um pequeno texto escrito por Mário, em fevereiro de 1922, endereçado a Anita Malfatti, em que ele relata poeticamente o encontro no qual pousou como modelo para o primeiro retrato que ela fez do amigo. Vale a pena a leitura do texto e da pintura ${ }^{2}$.

O encontro entre os dois personagens, Mário e Anita, atravessa a modernidade da cultura e, também, da arte/educação brasileira. Ele conhece as pinturas dela na famosa exposição de 1917, quando "foi 'avisado', como ele mesmo escreveria em 1928, 'da existência de uma arte contemporânea com que nem sonhávamos'. E este encontro se deu", como comenta Marta Rossetti Batista, "não através dos livros, do estudo e aceitação de novas teorias, mas pelo contato visual com uma nova pintura, de caráter expressionista" (BATISTA,1989, p. 19). Tornaram-se amigos em 1921, após uma segunda exposição dela, e desde então viveram uma amizade de mútuos contágios.

$\mathrm{Na}$ historiografia da arte e da cultura brasileira a presença dos dois é incontestável. No campo da arte/educação, Ana Mae Barbosa colocou-os em cena quando traçou o primeiro panorama da história do ensino da arte no Brasil nos seus primeiros livros de 1978 e 1982; deu visibilidade à coleção de desenhos infantis de Mário, quando realizou a exposição Mário de Andrade e a Criança, no Museu de Arte Contemporânea da Universidade de São Paulo (MAC/USP), em 1988, deixando um pequeno e provocativo catálogo como registro; publicou também um capítulo sobre ele no livro Tópicos Utópicos, de 1998. A coleção de desenhos infantis de Mário de Andrade foi por todas essas razões objeto de estudo de doutorado e as reflexões sobre sua atuação em torno dos desenhos, da criança e da educação continuam a ser foco de textos publicados (COUTINHO, 2002; 2008; 2016; 2017).

2 Retrato de Mário de Andrade I, 1922.

COUTINHO, Rejane Galvão. Anita, Mário e a modernidade da arte/educação brasileira. 


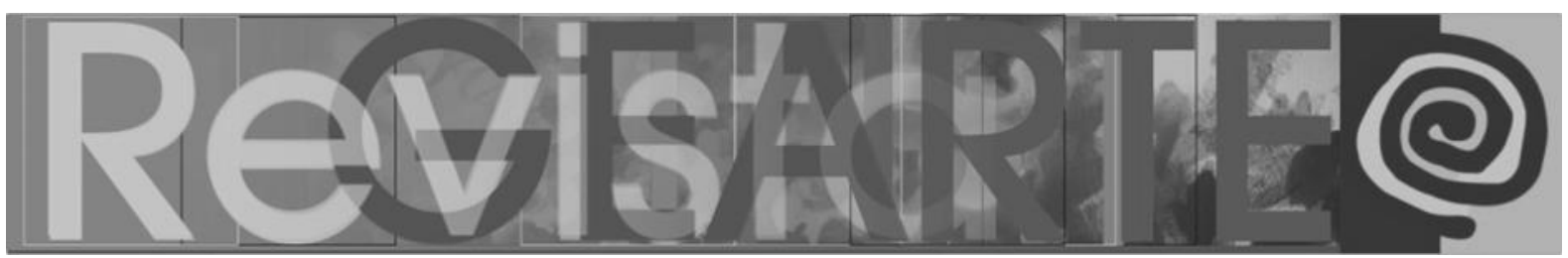

Aproveito aqui a oportunidade desse ensaio para trazer à cena Anita Malfatti, que foi extensamente estudada por Marta Rossetti Batista (2006), e mereceu uma pesquisa de Cibele Regina de Carvalho (2007), especialmente sobre sua atuação docente ao longo de mais de 30 anos como professora/artista. As duas pesquisas são importantes referências para o desafio que nos propomos fazer: relacionar os dois personagens tendo como foco um plano de ensino de desenho para crianças, do antigo ensino primário, hoje fundamental I, que Anita Malfatti deixou datilografado, com os desenhos da coleção Mário de Andrade. Diante desses dois documentos - se assim podemos nos referir à coleção de desenhos - deixados inconclusos, por isso abertos a interpretações, ousamos exercitar nossa imaginação relacionando-os.

A coleção de desenhos do Mário tem tido visibilidade no meio acadêmico e educacional com exposições e pesquisas. Importa reforçar que ele colecionou os desenhos exatamente no período em que viveu essa relação de amizade com Anita, na década de 1920 e, sobretudo, na década de 1930. O interesse de Mário sobre o assunto se revela, também, em sua biblioteca onde se encontram autores seminais nos estudos sobre a expressão gráfica e plástica das crianças, como Georges Rouma (1913), George-Henri Luquet (1927) e o brasileiro Sylvio Rabello (1935), entre outros.

Anita Malfatti desenvolveu este plano de ensino, ao que tudo indica, em 1930, quando dava aulas de Desenho na Escola Americana, o Mackenzie College, tendo na ocasião comentado em entrevista publicada em jornal ${ }^{3}$ que estava organizando um livro sobre o seu método de ensino para crianças.

\section{Sobre o contexto}

O olhar de Anita e de Mário para a produção gráfica e plástica das crianças foi instigado pelo contexto da modernidade artística. Mário, como esteta, buscava

3 "Mostrando às crianças os caminhos para a sua formação artística". Correio da Tarde. São Paulo, 1 de dezembro de 1930. Recorte de jornal pertencente ao Arquivo Anita Malfatti, IEB/USP. 


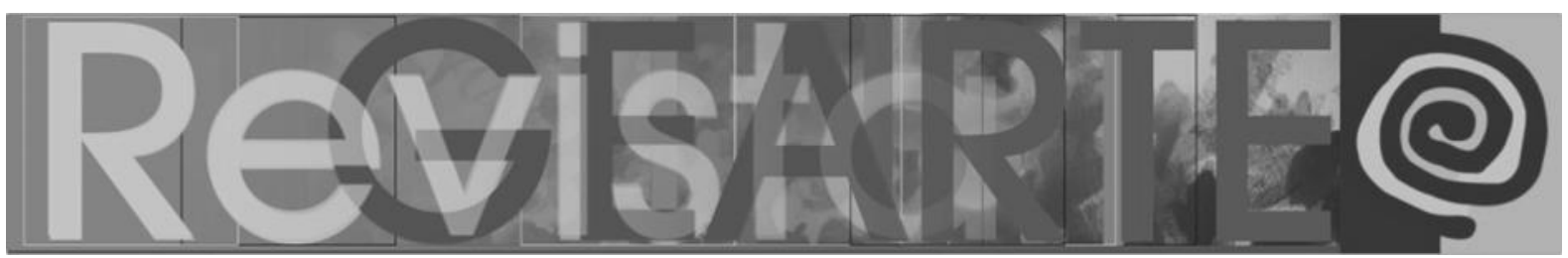

entender o "nascimento da arte", assim como Luquet e tantos outros filósofos e historiadores da cultura, de finais do século XIX e início do século $X X$, pesquisando e comparando as produções gráficas de povos ditos "primitivos" com desenhos de crianças. A teoria da recapitulação, então em voga, deu visibilidade a uma produção até então pouco conhecida, sobretudo, reconhecida por suas qualidades artísticas e/ou estéticas. Mário olhava para a produção das crianças buscando entender, ou mesmo crer, no que lia sobre o assunto e encontrava nos desenhos que observava, uma produção resultante dos processos de ensino de sua época, pois os desenhos que teve acesso na década de 1920 eram oriundos de contextos escolares. Ele assumiu, então, a postura de um pesquisador/colecionador e, em meados da década 1930, instituiu um concurso de desenhos entre crianças, em um ambiente que lhe parecia favorável, pois distante da educação formal, nos parques infantis, um projeto do Departamento de Cultura da Cidade de São Paulo, que oferecia atividades de recreação e esporte em equipamentos apropriados para crianças no contraturno escolar, em bairros operários. Os desenhos desse concurso se integraram à sua coleção e, apesar dos cuidados de não interferência dos adultos e de bons materiais de desenho, o que Mário observou é que a grande maioria dos desenhos coletados eram resultante dos processos de ensino já verificados nas escolas. E como era esse processo de ensino de desenho que se interpunha à observação de Mário de Andrade?

Figura 1 - Desenho n. 654, Gelcy Trajano, Parque da Lapa, 1937, 20 × 30 cm, grafite e lápis de cor

Fonte: Coleção de Desenhos Infantis, Acervo Mário de Andrade, IEB/USP. 


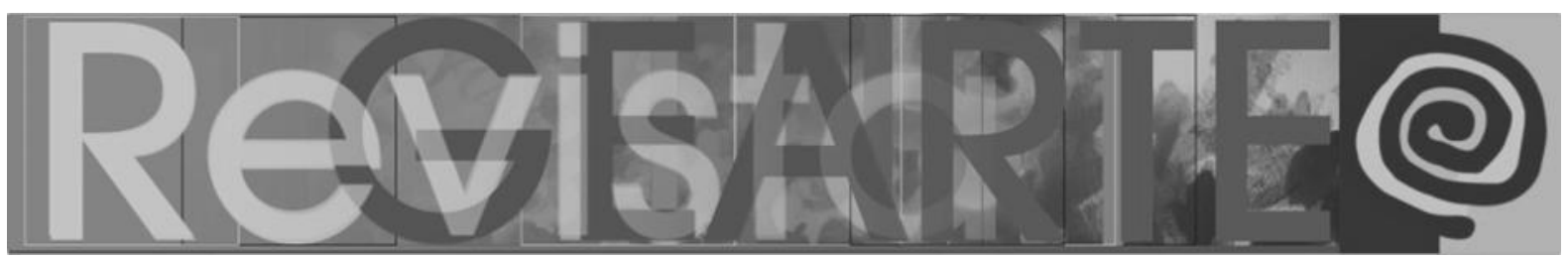

Nos programas curriculares das escolas primárias e secundárias brasileiras existia desde o século XIX a disciplina de Desenho, na qual os conhecimentos e habilidades técnicas e de cunho estetizantes das artes visuais eram ensinados. Essa disciplina passou a ter maior relevância no final do século XIX, quando o sistema educacional procurava se organizar e responder à demanda de uma sociedade em vias de industrialização. Nesse momento, a expansão do ensino primário e das escolas normais para a formação dos professores e a criação das escolas de artes e ofícios de cunho profissionalizante impulsionou o debate em torno do desenho como uma linguagem fundamental e um instrumental necessário para o desenvolvimento de habilidades e de raciocínios específicos, além da difusão de valores estéticos.

No livro Arte-Educação no Brasil (1978), Ana Mae Barbosa situa bem o ensino dessa época, que apontava em duas direções que coexistiam no mesmo sistema. Por um lado, havia a orientação do ensino do desenho técnico fundamentado na geometria, que mantinha relações próximas com uma perspectiva científica para auxiliar a formação de mão de obra especializada para a indústria em crescimento, e que trazia a marca das experiências das escolas inglesas e norte-americanas. Por outro lado, os programas de desenho sofriam também uma orientação de cunho estético, preocupada com os aspectos ornamentais e utilizando uma metodologia do desenho do natural ou cópia de estampas. Esta orientação estava carregada de conceitos engendrados pelas metodologias utilizadas na Escola de Belas Artes de influência francesa, que era responsável pela formação de boa parte dos especialistas na matéria. $\mathrm{Na}$ análise da autora percebemos a preponderância de uma ou outra dessas orientações na sequência de reformas que procuravam adequar e atualizar os programas de ensino nos diferentes níveis de educação desde o final do século XIX e que se estenderam durante as duas primeiras décadas do século $\mathrm{XX}$.

É importante situar, nesse panorama, como se configurava o ambiente das escolas normais de formação de professoras em relação à questão do desenho no período, pois eram essas professoras que efetivavam esse ensino nas escolas 


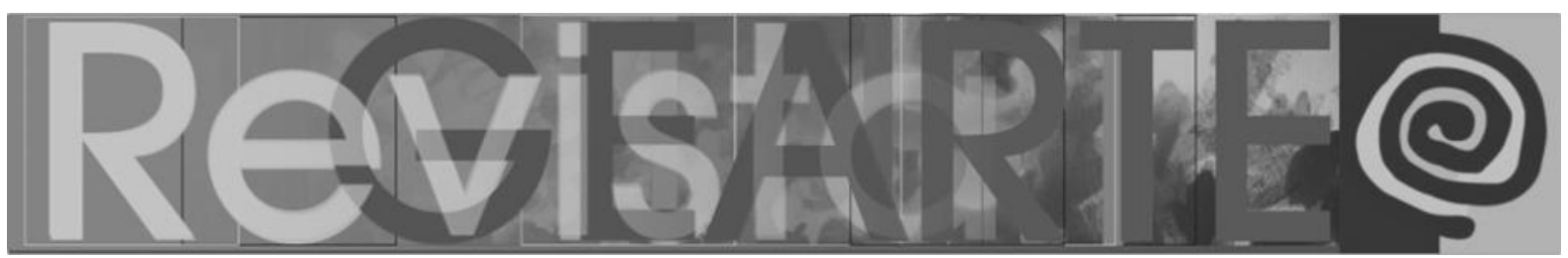

primárias. As orientações estéticas embutidas nos programas de Desenho oscilavam também, ora com uma tendência mais liberal e romântica, que admitia o uso de modelos naturais e a expressão individualizada da criança, ora uma tendência mais positivista, que recomendava a cópia de modelos pré-fabricados em gesso ou as famosas estampas que divulgavam o repertório neoclássico (BARBOSA, 1978). Vale salientar que a questão da ornamentação era contemplada em ambas orientações, tanto a ornamentação que tinha por base a estilização de motivos naturais, como a ornamentação geométrica feita a partir de modelos, em geral os ornatos derivados do estilo art nouveau.

Figura 2 - Desenho n.1329, Oswaldo C. Dias, escola, 1926, 15 x 23 cm, grafite e lápis de cor

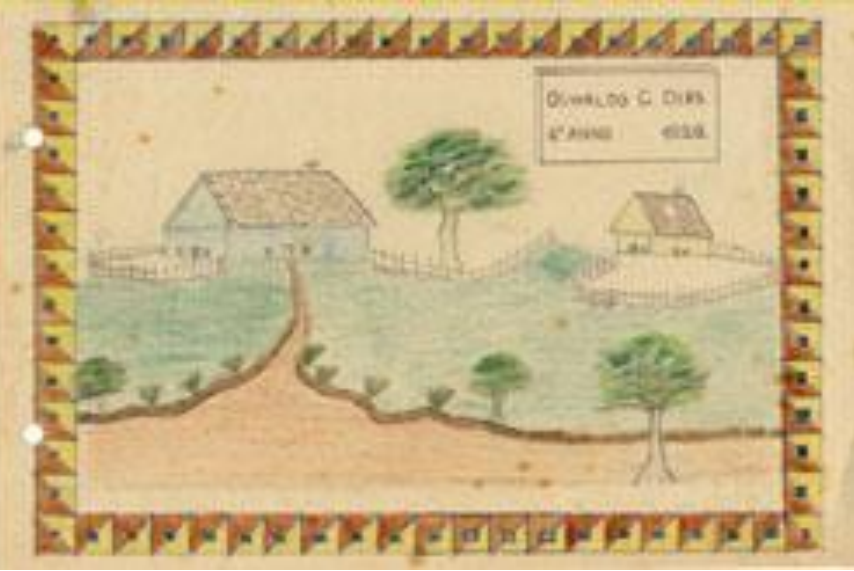

Fonte: Coleção de Desenhos Infantis, Acervo Mário de Andrade, IEB/USP.

Por vários indícios sabemos, também, que nessa época as informações sobre o desenvolvimento do grafismo da criança estavam chegando às escolas normais pela via da psicologia e da pedagogia experimental. Quando estudamos o livro do professor da Escola Normal de Pernambuco, Sylvio Rabello, Psicologia do Desenho Infantil (1935), tivemos acesso a um programa da Cadeira de Psychologia Geral e Applicada à Educação, de 1930, em que se encontravam tópicos sobre a criança e seu desenho. Vale salientar que a reforma da Escola Normal de Pernambuco, da qual o referido programa fazia parte, teve como modelo as reformas do Rio de Janeiro e de São Paulo.

Outro indício é a publicação de 1914, com título Laboratório de Pedagogia Experimental, que trata da implantação e das primeiras pesquisas do Gabinete de 


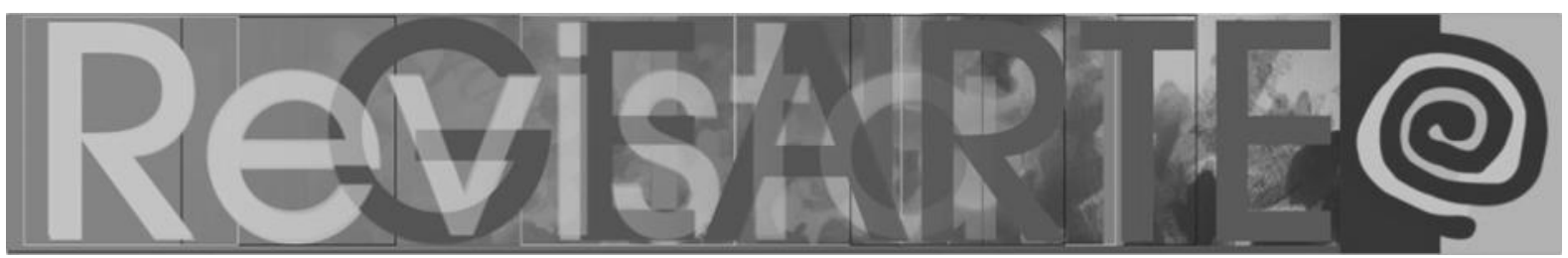

Psicologia e Antropologia Pedagógica, que funcionava anexo à Escola Normal de São Paulo, publicação que apresenta o resultado de algumas pesquisas que usavam o desenho infantil como recurso e assunto, dando conta de que o tema estava em pauta nesse contexto.

São indícios que dão pistas da aproximação das informações sobre o desenho infantil e a produção de algumas pesquisas sobre o assunto no ambiente educacional brasileiro, mas sabemos que a modificação do olhar dos educadores em relação à essa produção aconteceu lentamente. Foram necessárias ações em vários âmbitos, como nos textos das reformas educacionais do final da década de 1920 e início dos anos 1930, que procuravam sintonizar o sistema educacional brasileiro com as ideias progressistas da Escola Nova, em que encontramos reforços à questão do desenho infantil como instrumento pedagógico. Esses textos chamam a atenção dos educadores para a necessidade de olhar essa produção de maneira diferenciada e respeitosa. Por exemplo, em conferência realizada em fevereiro de 1930, na Sociedade de Educação de São Paulo, quando apresentava os pressupostos da Reforma, Fernando de Azevedo explicava que:

\begin{abstract}
O desenho, que constitui uma necessidade para a criança, mesmo antes da idade escolar, não se pode considerar uma atividade isolada das matérias que se estudam na escola primária. Ele coopera, de maneira notável, para a compreensão e retenção desses conhecimentos naqueles alunos, em que já se encontra desenvolvido o instinto de observação e que têm, no meio que os rodeia, no lar, na escola e nas suas excursões, sempre em relação com o ensino primário, a base de seus trabalhos. É certo que aos mestres, antes de tudo, numa clara compreensão da psicologia do desenho infantil, cabe respeitar a originalidade e ingenuidade dos desenhos das crianças, que não são na primeira idade, resultado de observação da natureza, mas representações plásticas de seus estados de alma, impregnados de tal ingenuidade e franqueza na sua expressão infantil, que os torna às vezes ininteligíveis para os adultos. Os próprios desenhos das crianças, ainda quando participam de uma certa observação do natural como expressão de seus instintos de observação, têm sempre uma grande 'parte de fantasia', isto é, criação absolutamente original do aluno, que é seguramente uma das mais interessantes e poderosas características dos desenhos infantis. (AZEVEDO, 1958, p. 125-126)
\end{abstract}

Enquanto o ambiente educacional se deixava permear muito lentamente, 0 ambiente artístico das primeiras décadas do século XX estava sendo sacudido pelas novas concepções modernistas do expressionismo, do fauvismo e outros 


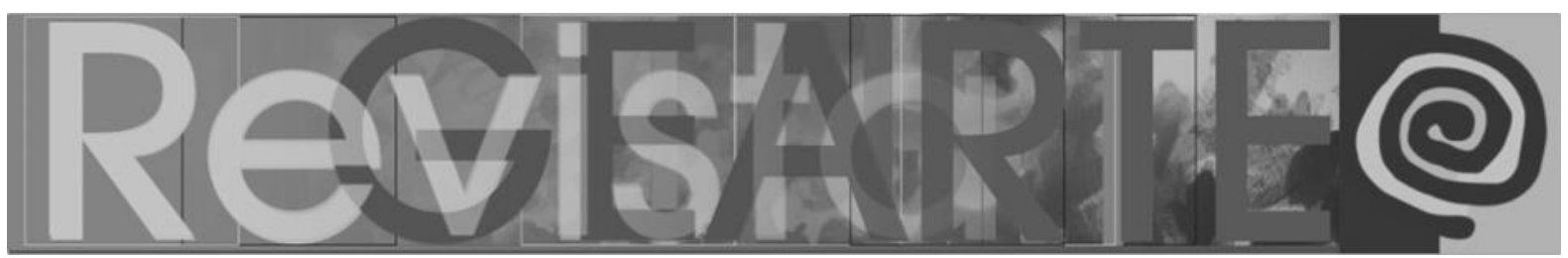

ismos, que olhavam também para as produções das crianças com interesse crescente. Um caso interessante e pouco conhecido é do escultor e professor alemão Wilhelm Haarberg que trabalhava e dava aulas em São Paulo, quando Mário de Andrade o conheceu em 1921 e o convidou para fazer parte da Semana de $22^{4}$. Em fevereiro de 1923, num artigo publicado na Revista do Brasil em que fazia uma avaliação das exposições que fecharam o ano de 1922, Mário de Andrade citou a exposição dos artistas alemães residentes no Brasil e depois de elogiar o trabalho artístico de Haarberg, comentou:

\begin{abstract}
Além de artista o Sr. Haarberg é excelente professor. Imprimiu uma orientação clarividente ao seu curso de plástica na Escola Alemã, e os trabalhos expostos de seus pequeninos alunos deram à exposição uma de suas mais vivas atrações. Com que tristeza me pus a comparar esta gente mal instruída brasileira, que não pode ver um desenho sem perguntar "onde estão os olhos?", com esses meninos educados na justa noção de arte, capazes de compreender a escultura como o jogo da luz e volume!... Amargor! Mas, não faz mal! O sentimento de humanidade vencerá talvez um dia o preconceito das pátrias restritas. Esses meninos serão homens em breve; e é pelo exemplo de espíritos assim educados que o gosto artístico da humanidade progredirá. (ANDRADE, 1923, p. 140)
\end{abstract}

Figura 3 - Desenho n.1926, Herbert Mayer, (8 a 10 anos), Escola Alemã, 1934, 25 x 15 cm, guache

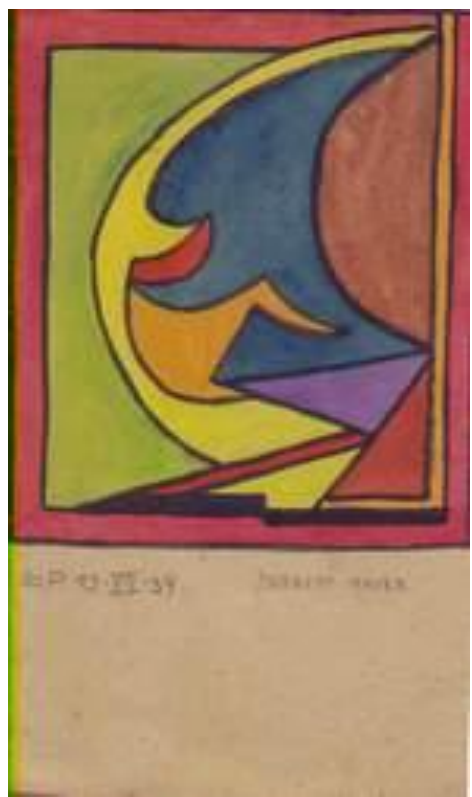

Fonte: Coleção de Desenhos Infantis, Acervo Mário de Andrade, IEB/USP.

4 Informações sobre o artista Wilhelm Haarberg do folder da exposição: Centenários Modernistas I: Wilhelm Haarberg (1891-1986), realizada no período de 22 de maio a 5 de julho de 1991 no IEB/USP com curadoria de Marta Rossetti Batista. 


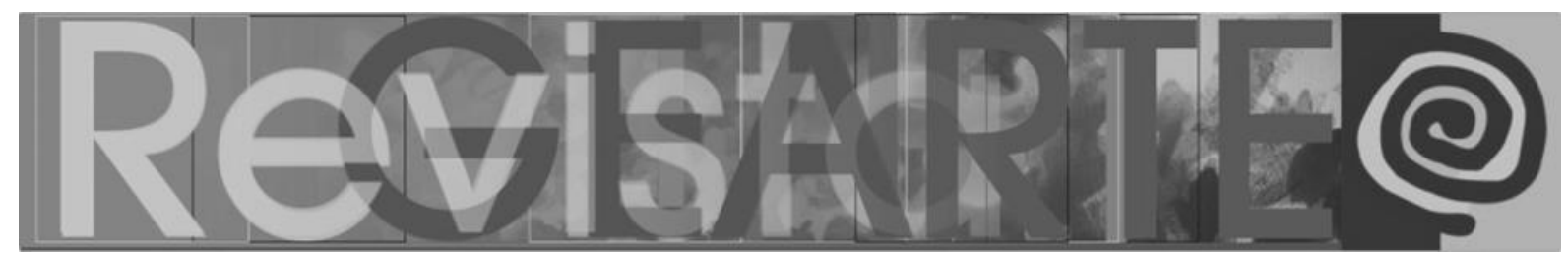

Figura 4 - Desenho n.1928, s/autor, (8 a 10 anos), Escola Alemã, 1934, 15 x 18 cm, guache

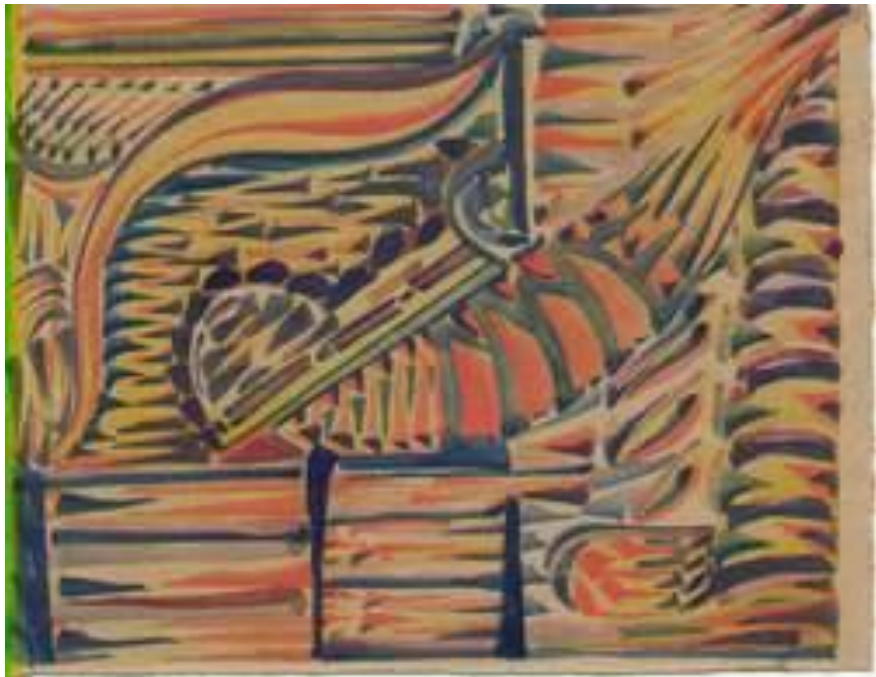

Fonte: Coleção de Desenhos Infantis, Acervo Mário de Andrade, IEB/USP.

É interessante perceber que a ação dos professores/artistas modernistas em relação à produção da criança nos chega hoje através de alguns registros de exposições. Fez parte da entrada da produção infantil no mundo da arte a situação de apreciação dessa produção com seus valores estéticos. No texto da conferência já citada de Fernando de Azevedo sobre a arte na reforma da Escola Nova, ele também fez menção a essa situação de apreciação da produção artística infantil no ambiente escolar, analisando seus objetivos e chamando atenção para a não interferência dos adultos na produção exposta. Ele afirmava:

As exposições de arte infantil, serão, por isto, tanto, mais expressivas e de tanto maior alcance educativo quanto mais revelarem e conservarem nos trabalhos apresentados, como nos primeiros desenhos livres, (...) a sincera espontaneidade, manifestada no seu caráter original, isto é, na absoluta abolição da cópia e na maior ausência possível de influências prejudiciais. O desenho como atividade espontânea e criadora, e os trabalhos manuais, com os novos processos adotados pela reforma, devem levar as crianças à convicção de que podem desenhar, modelar e construir o que querem, sem necessidade de copiar, proporcionando-lhe a oportunidade de se exprimirem, por meio do desenho ou da massa plástica, com as características fundamentais de seus trabalhos, sinceros e ingênuos, que tendem a perder o caráter infantil à medida que se vão aproximando das manifestações artísticas dos adultos. Essas exposições, realizadas com probidade, poderão não satisfazer aos olhos de adultos, pais ou professores, que não estão integrados do espírito da educação nova, e, não conhecendo a psicologia do trabalho infantil, julgam o seu valor artístico pela mentalidade e pela técnica de sua própria idade; mas se o valor dos trabalhos se deve medir pelo coeficiente de fantasia ou de criação original do aluno e pelo progresso artístico dentro 


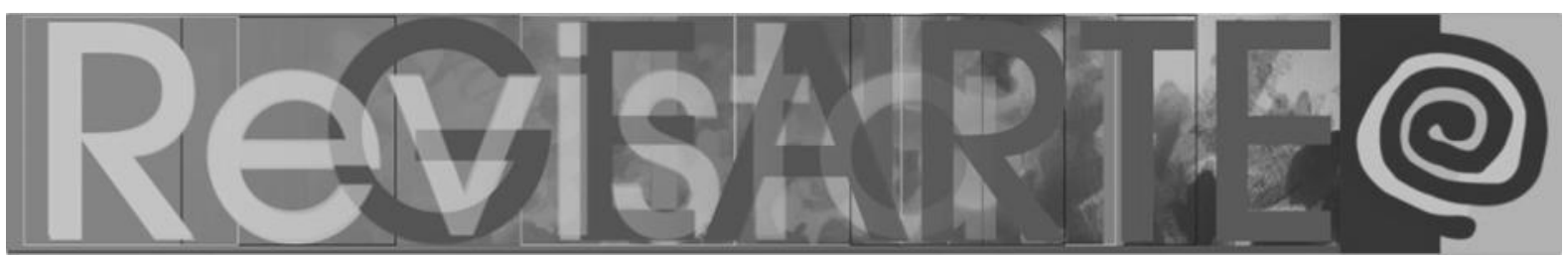

das forças infantis, e se o objetivo do método e da técnica do novo ensino do desenho, nas escolas primárias, é conservar, ainda em crianças de maior idade, a sincera espontaneidade de seus trabalhos, isto é, a expressão da personalidade da criança; nada de certo mais contrário às exposições de arte infantil e à sua finalidade, do que essas exposições, vulgares ou anódinas, em que, longe de vibrar, magnífica na sua ingenuidade, a alma das crianças, mal se dissimula, na procura do efeito, tirando-lhes o caráter documentário, quando não a mão impaciente do professor, toda sorte de influências estranhas, artificiosas e deformadoras". (AZEVEDO,1958, p. 126)

\section{Sobre Anita e sua formação}

Foi nesse contexto que Anita Malfatti iniciou sua atuação como professora em paralelo com a sua já reconhecida atuação como pintora. A opção pelo magistério foi uma condição dada pelas circunstâncias de sua vida, meio conjugado de sobrevivência. A influência de sua mãe, D. Bety Krug Malfatti, que ficou viúva ainda jovem e com filhos pequenos, voltando a dar aulas e mantendo sua atuação como pintora, parece ter sido um exemplo forte.

Anita começou em 1921 e continuou em 1922 oferecendo um curso livre de desenho e pintura no Mackenzie College, escola onde ela havia terminado o ensino secundário. Era um "curso misto, sem restrições de idade e independente das outras aulas" 5 . Nessa época, Anita já havia feito estudos na Alemanha entre 1910 e 1014 e em Nova York entre 1915 e 1917. No final de 1917 aconteceu a famosa "Exposição de Pintura Moderna Anita Malfatti", que tanto rebuliço causou no meio artístico e cultural de São Paulo. A sua primeira experiência como professora foi interrompida em 1923, quando ganhou o Pensionato Artístico do Estado de São Paulo e viajou para Paris, permanecendo na Europa até 1928.

No seu retorno Anita voltou a dar aulas na Escola Americana, o Mackenzie College, entre 1930 e 1932 - aulas de Desenho no ensino primário e no curso normal, para formação de professoras. A partir de 1933, deixou as classes escolares e passou a dar aulas apenas em seu ateliê até 1952.

5 Segundo reprodução do folheto de divulgação do curso no livro de Marta Rossetti Batista, 2006, p. 266. 


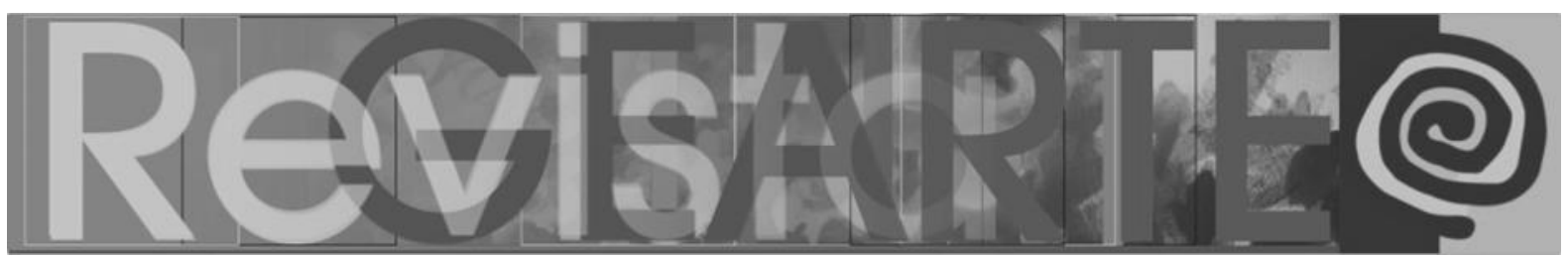

Nos dois anos em que Anita trabalhou com crianças e preparando jovens professoras idealizou escrever "um livro com ilustrações sobre os variados aspectos do seu modo original, prático e eficiente de ensinar às crianças a arte." A reportagem na qual consta essa informação foi publicada em 1 de dezembro de 1930 e foi motivada por uma exposição dos trabalhos de seus alunos. Chama a nossa atenção hoje o fato de que a artista, já reconhecida como "a notável pintora moderna paulista", não foi apresentada como professora de Desenho, mas como aquela que vai mostrar "às crianças os caminhos para sua formação artística", como indica o título da reportagem que termina com este comentário sobre seu método "eficiente de ensinar às crianças a arte". Podemos considerar que estamos aqui nos primórdios de um movimento em prol da arte/educação brasileira, ensinando arte e cuidando da formação artística, não apenas ensinando desenho.

Este posicionamento revela que Anita estava em sintonia com as novas questões postas pelos pesquisadores dos campos da arte, da psicologia e da educação e mesmo da história da cultura. Nos primeiros anos de estudo em Berlim, entre 1910 e1914, ela possivelmente teve contato, seja através de exposições ou de conversas no meio artístico, com as pesquisas dos historiadores e antropólogos que trabalhavam sob a perspectiva da recapitulação buscando entender o nascimento da arte, relacionando produções dos "primitivos" com produções das crianças, pois essas pesquisas foram divulgadas em exposições e algumas delas junto com obras de arte moderna. Podemos até imaginar que Anita tenha tido informações sobre as classes de Franz Cizek, que aconteciam em Viena entre 1897 e 1938, pois as classes de Cizek tiveram visibilidade tanto nos meios artísticos quanto educacionais dessa época.

Importante também considerar a sua formação em Nova York, entre 1915 e 1917, quando John Dewey estava ativamente divulgando suas ideias no meio educacional norte-americano. As experiências vivenciadas por ela na Independent School of Art, com o artista e professor Homer Boss, podem ser alinhadas com o conceito de aprendizado pela experiência defendido por Dewey, pois o professor Boss levava os jovens artistas a vivenciarem experiências antes de as 


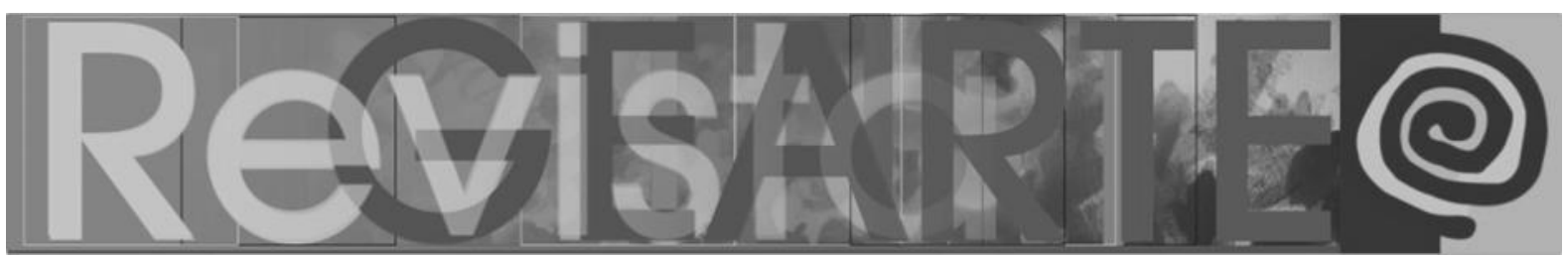

expressarem em telas. Um dos exemplos relatados por Anita foi uma travessia num veleiro em mar aberto para viver e sentir a experiência do mar, para só depois expressá-la na pintura.

\section{Sobre o plano de ensino e o método de Anita}

A experiência de Anita Malfatti como professora no Mackenzie College aconteceu justamente no período em que as reformas progressistas que divulgavam o ideário da Escola Nova estavam em pauta. Segundo Cibele R. Carvalho (2007, p. 86), uma das escolas que foi usada como modelo por Caetano de Campos para a reforma de São Paulo foi o Mackenzie, que se apresentava, então, como uma escola progressista com classes mistas e que tinha como orientação as ideias filosóficas e educacionais de Horace Mann e John Dewey.

Para entender o método desenvolvido por Anita temos o Plano de ensino de desenho, documento que se encontra entre os textos originais, manuscritos e datilografados do arquivo de Anita Malfatti do Instituto de Estudos Brasileiros da Universidade de São Paulo (IEB/USP). Junto com o plano temos a já citada reportagem feita a partir de entrevista concedida por ela a um jornalista e também o artigo escrito por Mário de Andrade, publicado no Diário Nacional em 23 de novembro de 1930, com título Pintura Infantil, no qual comenta a mesma exposição que se refere a reportagem.

Visto que na época se apresentavam também outros planos de ensino de desenho, como o de Theodoro Braga, de 1920, analisado por Ana Mae Barbosa (1978, p. 93-94) e retomado recentemente (COUTINHO, 2017), o plano de Anita se apresenta de forma sucinta como um corpo estrutural de um curso, que ensaiamos dar substância ao relacionar com desenhos que poderiam ter sido fruto deste corpo em processo de crescimento/aprendizagem. Importante situar, ainda, que esse plano se endereça ao ensino primário da época, que recebia crianças a partir de sete anos no primeiro ano primário e assim em sequência. Dessa forma se apresenta o plano de ensino de Anita Malfatti: 


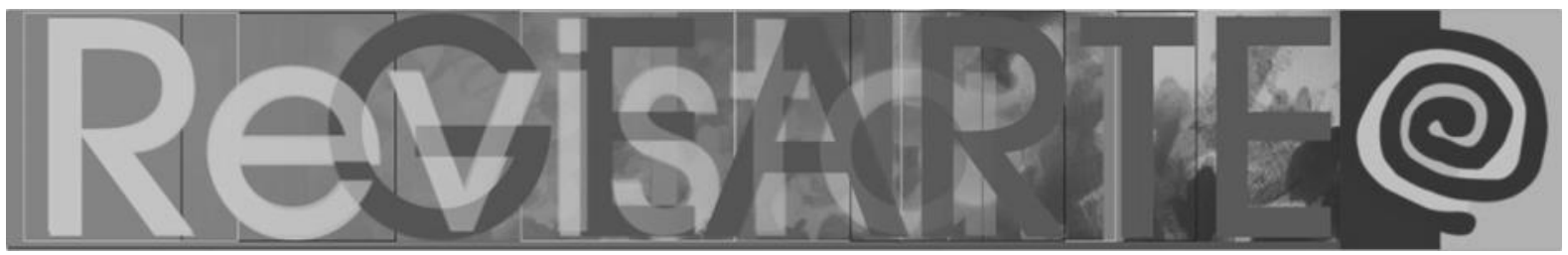

I Ano

Histórias ilustradas: um menino sai para passear e encontra uma certa casa, uma bandeira hasteada; faz continência. O desenho deve mostrar um menino em posição direita fazendo continência. Essas histórias podem ser contadas pela professora ou por um dos alunos.

Figura 5 - Desenho n. 989, Larrizabola, 1 ano B, Mackenzie, 1931, 16 x $22 \mathrm{~cm}$, grafite e lápis de cor

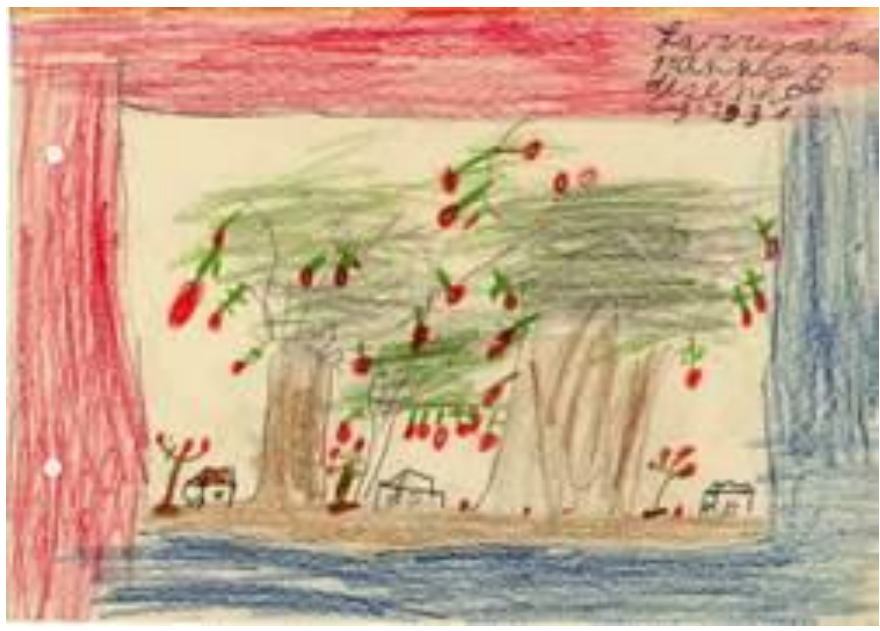

Fonte: Coleção de Desenhos Infantis, Acervo Mário de Andrade, IEB/USP.

Figura 6 - Desenho n. 987, Plirts Nebá, 1ำ ano, Mackenzie, 1931, 16 × 22 cm, grafite e lápis de cor

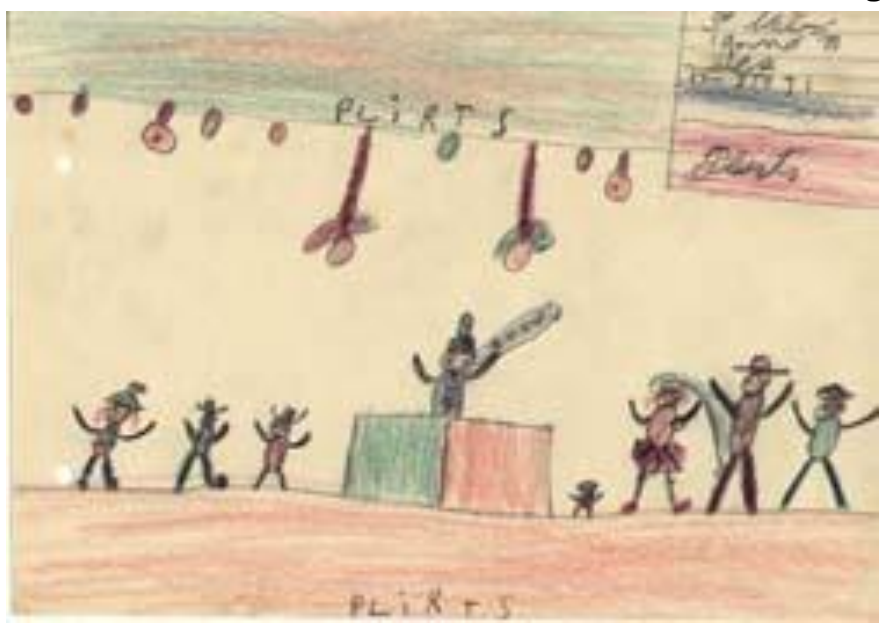

Fonte: Coleção de Desenhos Infantis, Acervo Mário de Andrade, IEB/USP.

A imagem que Anita usa para ilustrar o enunciado pode hoje ser lida com certa resistência, pois atrelada a um tema cívico, porém, destacamos como 


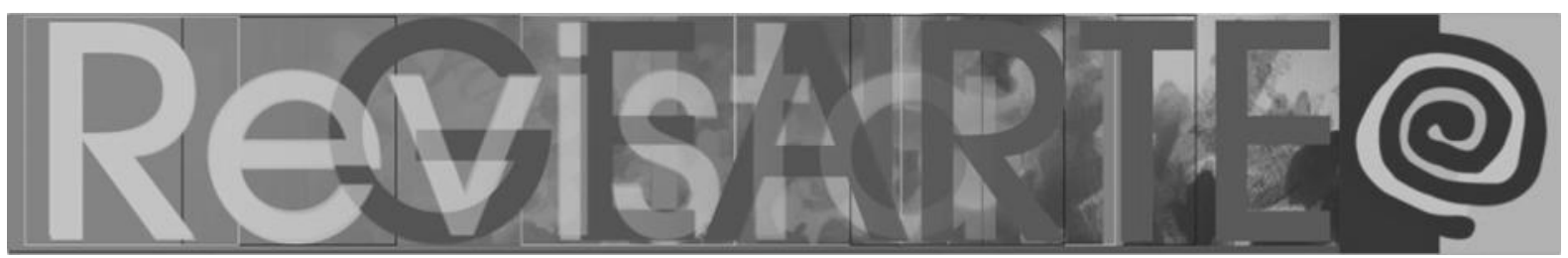

significativa a ideia de que os desenhos das crianças podem conter narrativas e de que é importante que se estimule a narratividade e a imaginação das crianças de sete a oito anos através de ilustrações de histórias que podem ser contadas pelo professor ou pelas próprias crianças. Anita deveria ter conhecimento sobre 0 percurso do desenvolvimento gráfico para não impor às crianças, que iniciavam sua escolarização, estratégias de desenhos de observação ou de cópias.

II Ano

Modelos em madeira, representando diversos animaizinhos ou objetos usuais. As crianças tatearão os modelos e procurarão representar com o lápis o que sentirem com os dedos. Os alunos começarão também a copiar os objetos que tiverem ao redor, tais como: lápis, caneta, pena, quadro, etc. Cada vez que for possível, para interessar as crianças, contar uma lenda qualquer a respeito do modelo.

Figura 7 - Desenho n. 73, Martha Miguel, concurso, 1937, 20 x $30 \mathrm{~cm}$, grafite e lápis de cor

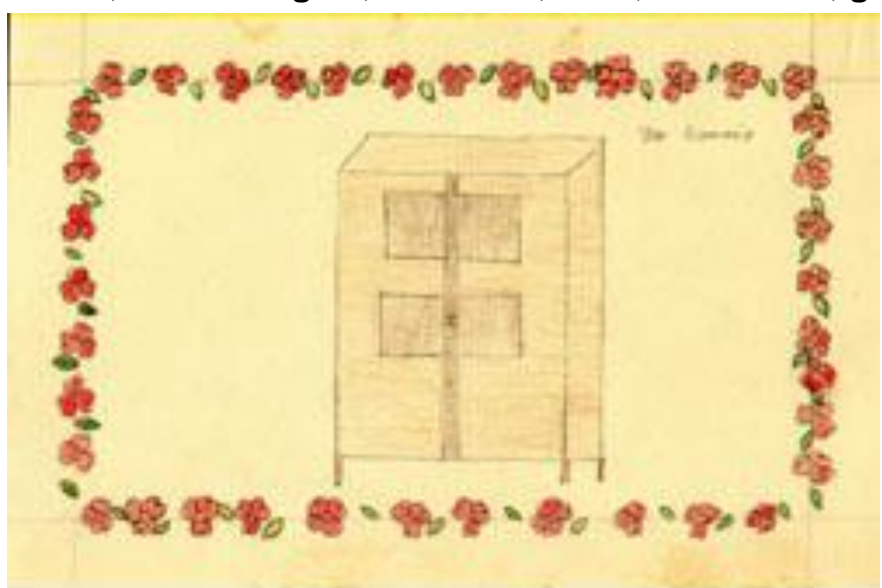

Fonte: Coleção de Desenhos Infantis, Acervo Mário de Andrade, IEB/USP. 


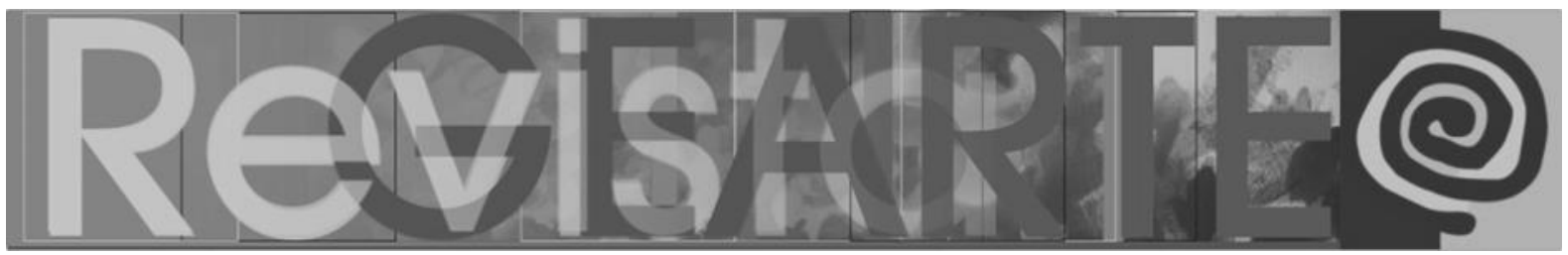

Figura 8 - Desenho n. 376, Laura Morales, concurso, 1937, 20 x 30 cm, grafite e lápis de cor

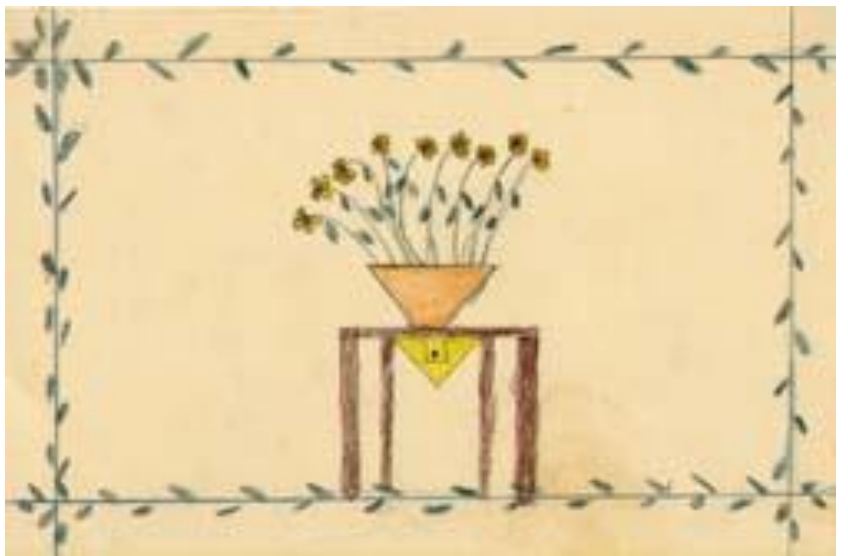

Fonte: Coleção de Desenhos Infantis, Acervo Mário de Andrade, IEB/USP.

Figura 9 - Desenho n. 240, Octavio Parrello, concurso, 1937, 20 × 30 cm, grafite e lápis de cor

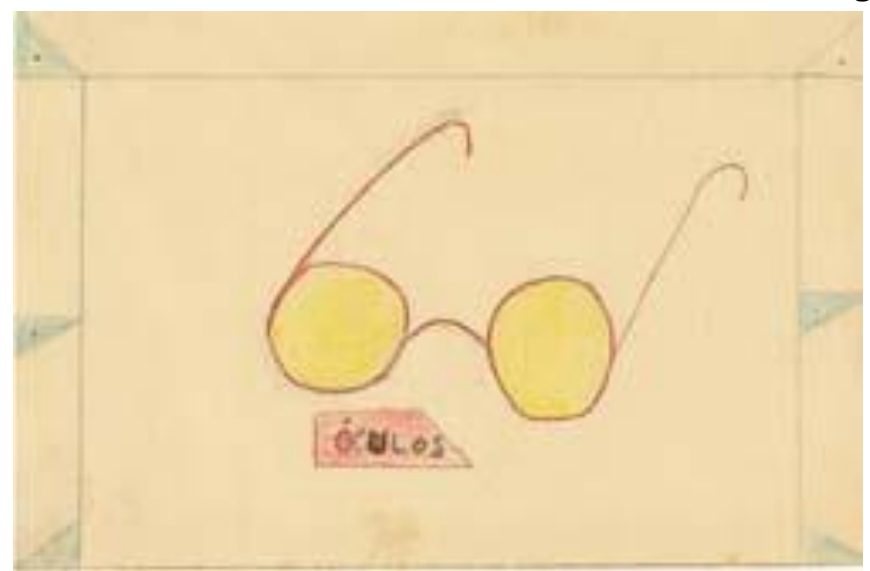

Fonte: Coleção de Desenhos Infantis, Acervo Mário de Andrade, IEB/USP.

Figura 10 - Desenho n.1532, Maria Apparecida Del Ponte, escola, s/data, 16 x $22 \mathrm{~cm}$, grafite e lápis de cor

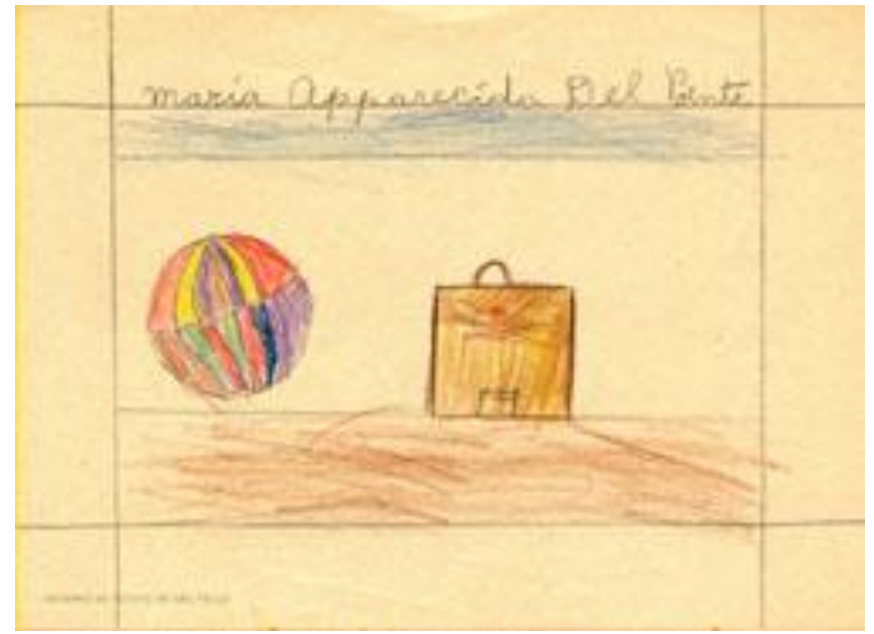

Fonte: Coleção de Desenhos Infantis, Acervo Mário de Andrade, IEB/USP. 


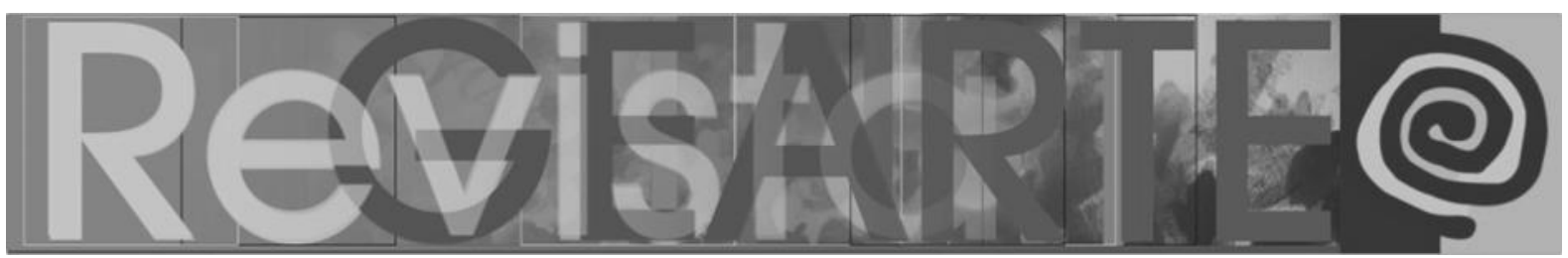

No segundo ano primário a indicação é para estimular a representação de brinquedos ou objetos usais que as crianças possam tatear para melhor conhecêlos com os sentidos antes de os representar. Na sequência sugere "copiar" os objetos que as crianças tenham ao redor, deixando a ideia de cópia a ser entendida como uma "representação". Importante também ressaltar o cuidado para que o repertório a ser desenhado seja conhecido das crianças, além de buscar estimular o interesse através de uma história ou lenda envolvendo o objeto a desenhar.

III e IV Anos

Para que as crianças adquiram facilidade em governar o lápis, dar-se-á uma série de modelos que elas copiarão. O professor tomará uma caixa, colocando-a numa posição qualquer e copiará no quadro negro. Os alunos copiam do modelo da pedra, mas é bom conservar a caixa na posição em que estava quando o professor copiou. No IV ano o professor fará questão de que as linhas retas sejam tendendo para a perfeição que é possível obter de tais alunos, e do mesmo modo com as curvas.

Figura 11 - Desenho n. 1665, Clara Stefani, Parque da Lapa, 1937, 20 × 30 cm, grafite e lápis de cor

Fonte: Coleção de Desenhos Infantis, Acervo Mário de Andrade, IEB/USP. 


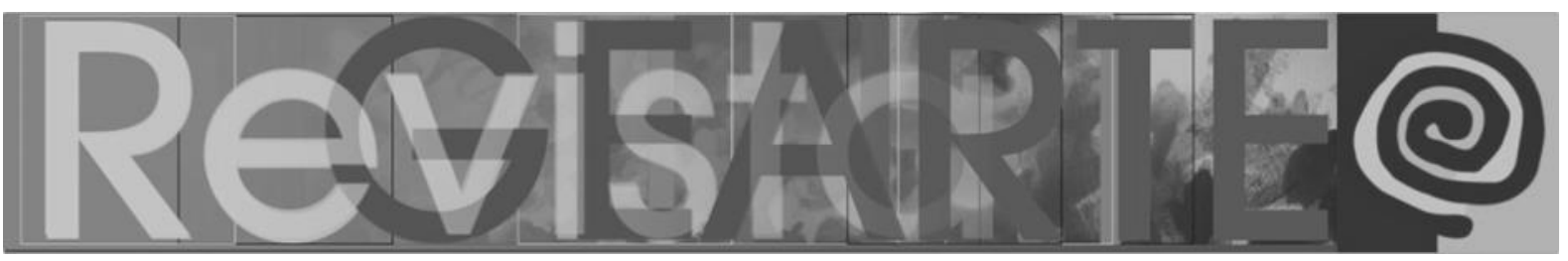

Figura 12 - Desenho n. 267, Cândida Rodrigues, s/local, 1937, 20 x 30 cm, grafite e lápis de cor

Fonte: Coleção de Desenhos Infantis, Acervo Mário de Andrade, IEB/USP.

No terceiro e quarto ano, para crianças de nove, dez e onze anos, o plano indica que o professor deve diversificar os modelos a serem "copiados", ou a serem representados, ampliando o repertório gráfico e exercitando a técnica para "governar o lápis". Introduz o desenho de observação sugerindo que o professor exemplifique a reprodução de um modelo simples, como uma caixa, diante das crianças e que mantenha o modelo e o resultado na lousa, indicando que as crianças devem copiar o desenho do professor. Há aqui subjacente a ideia tão defendida posteriormente por Brent Wilson, Al Hurwitz e Marjorie Wilson (1987) de que desenho se aprende de desenho, de que as soluções das representações de objetos tridimensionais em planos bidimensionais são uma conquista de nossa cultura e que não devemos negar às crianças esse conhecimento. Para o quarto ano, Anita observa ainda que o professor pode começar a exigir cuidado com as linhas retas e curvas, sem mencionar o uso de instrumentos, o que nos leva a ponderar que ela atribui ao exercício constante o domínio do traço.

VAno

A. Desenho Natural - Os alunos começarão a copiar exclusivamente de modelos naturais. Para este empregar diferentes modelos de potes, jarras, vasos, xícaras; tomará excessivo cuidado com as linhas curvas e começará a dar ao aluno uma ideia de sombra. 


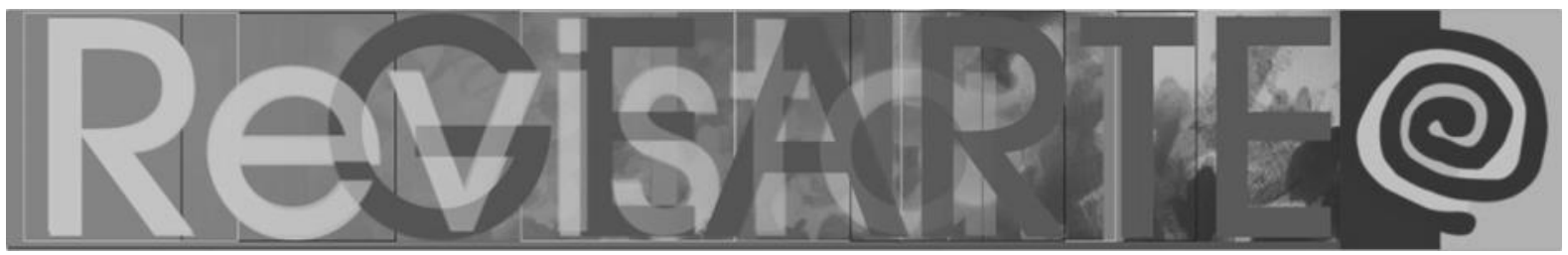

B. Terá para modelos objetos tais como: um livro em diversas posições, uma cadeira, um sapato, um chapéu, uma mala de viagem, um banco. O professor fará executar o mesmo modelo em diferentes posições.

Figura 13 - Desenho n. 982, Kenhu Shimomoto, escola, 1929, 16 x 23 cm, grafite e lápis de cor

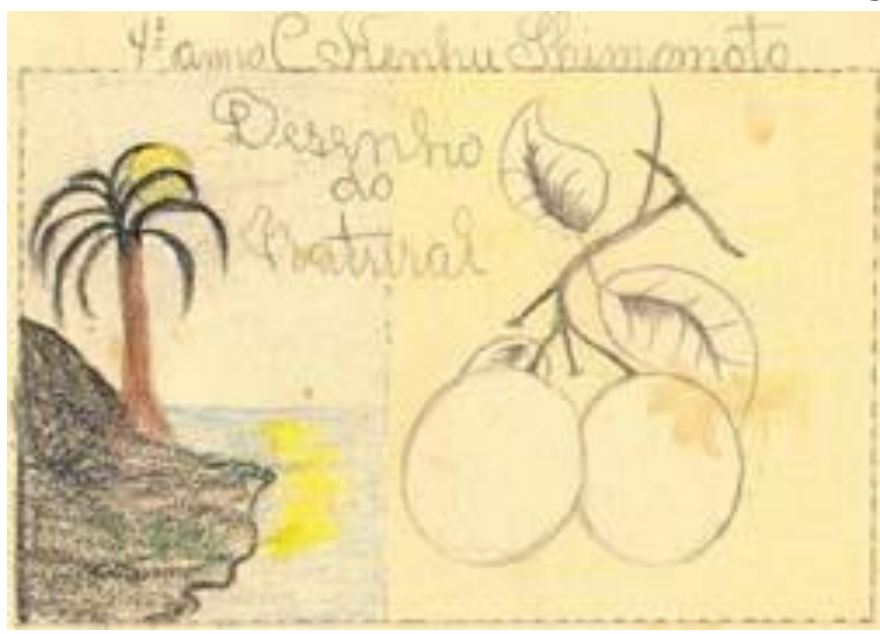

Fonte: Coleção de Desenhos Infantis, Acervo Mário de Andrade, IEB/USP.

Figura 14 - Desenho n. 405, Estevam Giagnori, concurso, 1937, 20 × 30 cm, grafite e lápis de cor

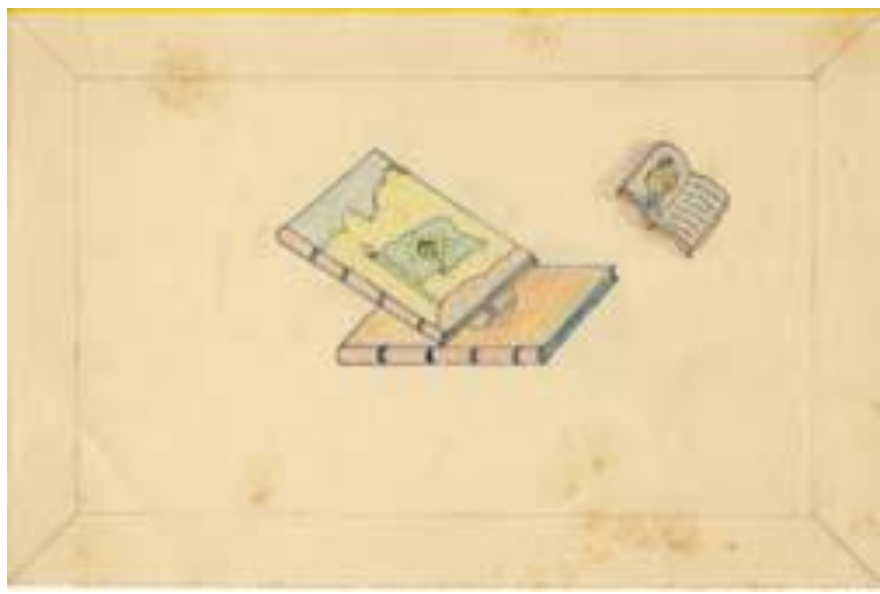

Fonte: Coleção de Desenhos Infantis, Acervo Mário de Andrade, IEB/USP. 


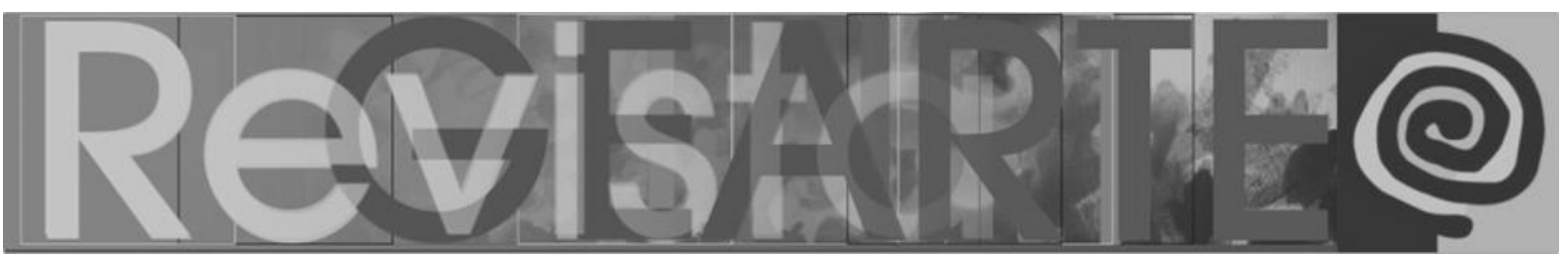

Figura 15 - Desenho n. 739, Herberto Silbiger, Biblioteca Infantil, 1937, 20 x $30 \mathrm{~cm}$, grafite e lápis de cor

Fonte: Coleção de Desenhos Infantis, Acervo Mário de Andrade, IEB/USP.

Figura 16 - Desenho n. 1951, Amaro Rozzenbak, Grupo Escolar de Santo Amaro, 4 ano, 1928,16 × $23 \mathrm{~cm}$, grafite e lápis de cor

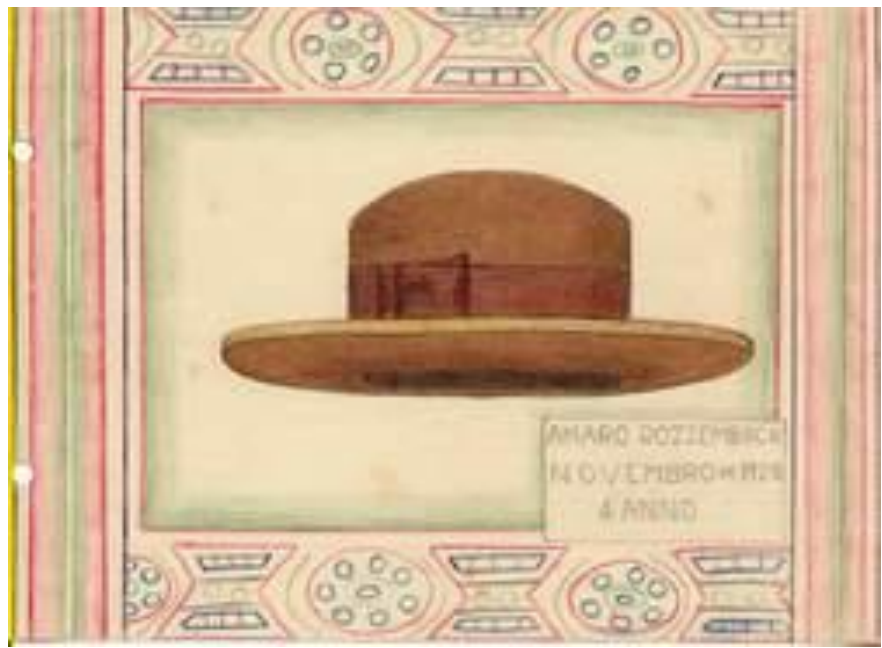

Fonte: Coleção de Desenhos Infantis, Acervo Mário de Andrade, IEB/USP.

Para o quinto ano, quando o estudante deveria estar com 11 ou 12 anos, a proposta menciona o "desenho do natural", uma terminologia muito usada na época, que faz parte do ideário acadêmico, uma proposta sinônima ao desenho de observação que teria como modelo objetos do mundo natural, como indicado no enunciado. Aliás, nos dois enunciados, as sugestões dadas revelam a vinculação de Anita com o ideário das academias que a professora/artista já havia frequentado em seu processo de formação, tanto fora do Brasil quanto quando teve aulas nos ateliês de Pedro Alexandrino e Elpons, no início da década de 1920, em São Paulo. 


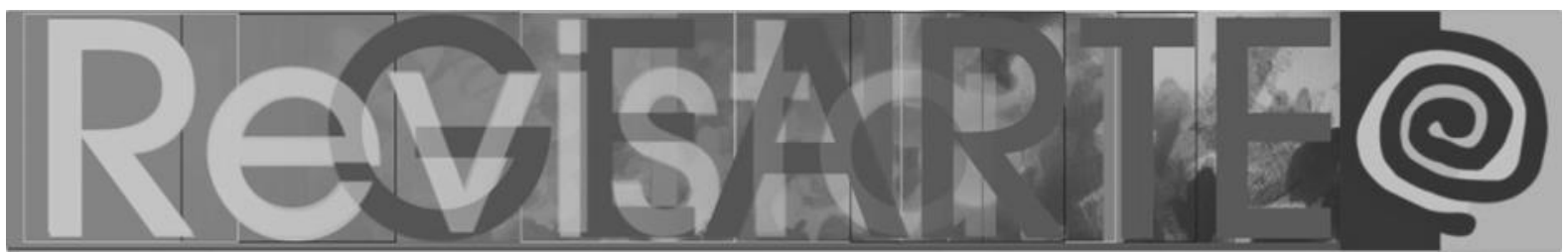

VI Ano A

Nos dois primeiros períodos os alunos farão estudos sobre folhas como modelos naturais. Nos dois últimos períodos terão para modelo indistintamente flores e frutas.

VI Ano B

Desenhar o quanto possível de modelos naturais, os diversos animais domésticos e outros animais; na medida do possível. Nos dois últimos, copiar pessoas.

Figura 17 - Desenho n. 1176, Guilhermina Fischer, escola, 1930, 16 x 23 cm, grafite e lápis de cor

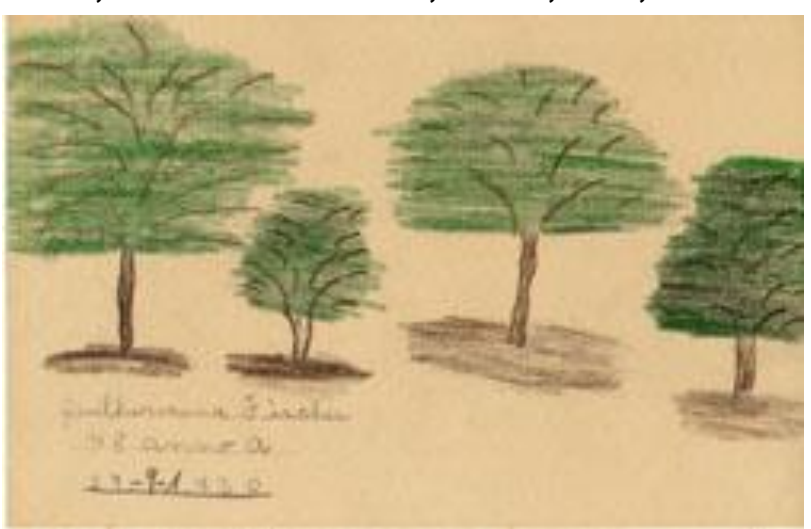

Fonte: Coleção de Desenhos Infantis, Acervo Mário de Andrade, IEB/USP.

Figura 18 - Desenho n. 680, Maria de Castro, Biblioteca Infantil, 1937, 20 × $30 \mathrm{~cm}$, grafite

Fonte: Coleção de Desenhos Infantis, Acervo Mário de Andrade, IEB/USP. 


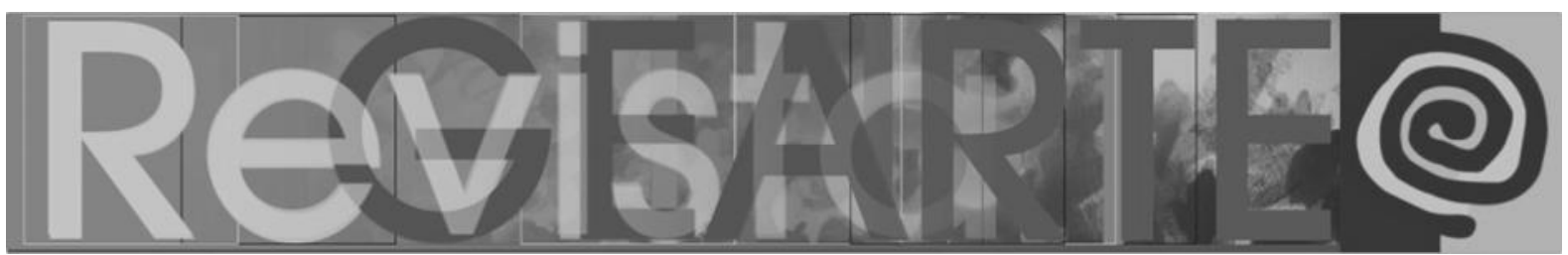

Figura 19 - Desenho n. 1280, José Martins, 13 anos, s/data, 17 x $16 \mathrm{~cm}$, grafite

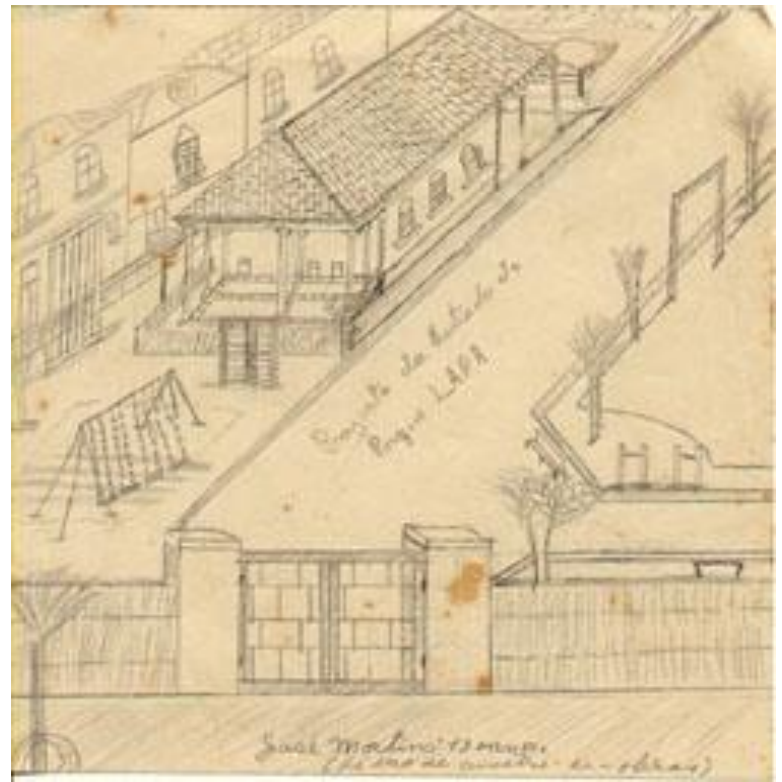

Fonte: Coleção de Desenhos Infantis, Acervo Mário de Andrade, IEB/USP.

E o curso finaliza com este duplo sexto ano A e B, dando sequência aos desenhos de observação de modelos naturais, primeiro com foco na própria natureza, para em seguida complexificar com a representação de animais, finalizando com o modelo vivo. O desenho do natural é a base na qual a professora estruturou seu programa, e observamos duas grandes diferenças entre esse e outros programas conhecidos da época, como o de Theodoro Braga. Primeira diferença é a não inclusão de tópicos relativos à ornamentação ao longo do programa, como era comum na época, e podemos observar nos desenhos da coleção Mário de Andrade aqui reproduzidos, as figuras 2, 7, 8, 11, 12 e 16. A segunda diferença é a clara orientação estetizante, alinhada com os preceitos acadêmicos, mas respeitando a expressividade da criança, do plano de Anita, que se distancia das perspectivas que preconizavam o desenho geométrico como centro da aprendizagem da disciplina Desenho.

Na reportagem publicada no Correio da Tarde a propósito da exposição dos trabalhos de seus alunos, no final de 1930, temos outras informações que dão indícios sobre as tendências que norteavam a execução de seu método em que podemos, também, vislumbrar a partir de quais pressupostos Anita percebia a 


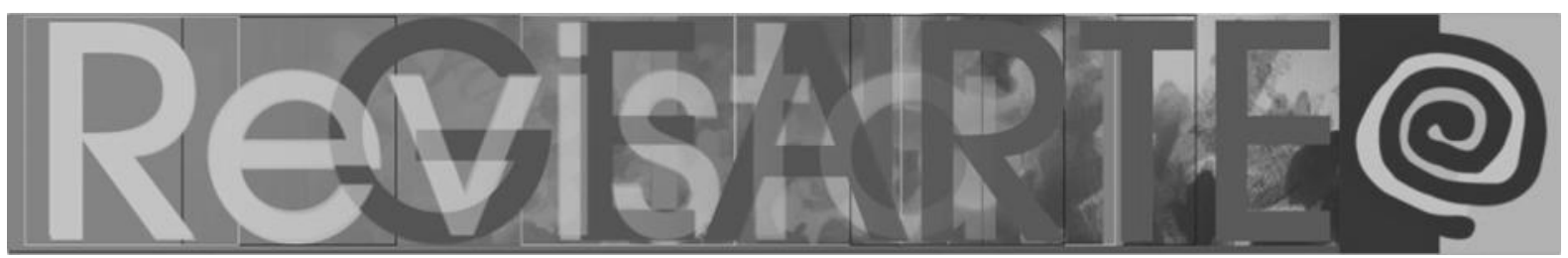

produção das crianças. É importante ter em conta que a reportagem foi escrita por um jornalista a partir de uma entrevista com a professora, ou seja, pode ter havido também interpretações sobre a sua fala.

De inúmeras observações, Anita Malfatti chegou a conclusão de que todo o indivíduo de inteligência normal pode ser um artista. Da mesma forma porque manifesta suas ideias e as consubstancias na escrita, igualmente pode expressar no desenho o seu pensamento e minunciá-lo das mais complexas formas imagináveis. Na criança normal, notadamente, é instintiva essa intuição artística. Para desenvolvê-la basta despertar no desenho essa afinidade criadora que a imaginação provoca. $E$ isso se consegue por um trabalho orientado cientificamente, tendente a forçar a criança a desenvolver sua ideia, inspirada na própria imaginação. Aproveitando-se dessa forma a técnica, procura-se exprimi-la de acordo com as qualidades básicas que cada criança possui. Nunca contrariá-la na sua inclinação, porém deixá-la manifestar o seu sentimento livremente. $\mathrm{O}$ que produz maior sensibilidade à índole infantil é justamente o que serve de motivo. ${ }^{6}$

Desse comentário, destacamos primeiro a desconstrução de uma ideia elitista de que para fazer arte é preciso ser um iluminado. Para Anita, qualquer indivíduo de inteligência normal pode ser um artista. Importante atentar para este verbo condicionante "pode ser", pois ela não estava afirmando que todos os indivíduos eram artistas, mas que aqueles que quisessem ser, poderiam ser, pois teriam instintivamente, o que ela nomeia como "intuição artística". E é também muito importante a afirmação de que para que essa intuição se desenvolva é necessário "um trabalho orientado cientificamente", ou seja, é necessário um processo de ensino e aprendizagem. Ainda nesse comentário se evidencia em várias passagens o respeito que Anita nutria pela expressão da criança, estimulando a imaginação, atenta às qualidades básicas de cada criança, buscando não contrariar suas inclinações. $\mathrm{Na}$ entrevista dada ao jornalista ela também tentou sintetizar o seu método:

Dessa exposição não se pode tirar senão uma conclusão do meu método - disse-nos Anita Malfatti: que ele é meramente mecânico e intuitivo, orientado por observações psicológicas que me induzem a aproveitar o sentimento do aluno. Dessa maneira não uso determinado assunto, porém, uma infinidade, promanados de uma sugestão do aprendiz, que se utiliza e se estimula.

6 Citação da reportagem "Mostrando às crianças os caminhos para sua formação artística". 


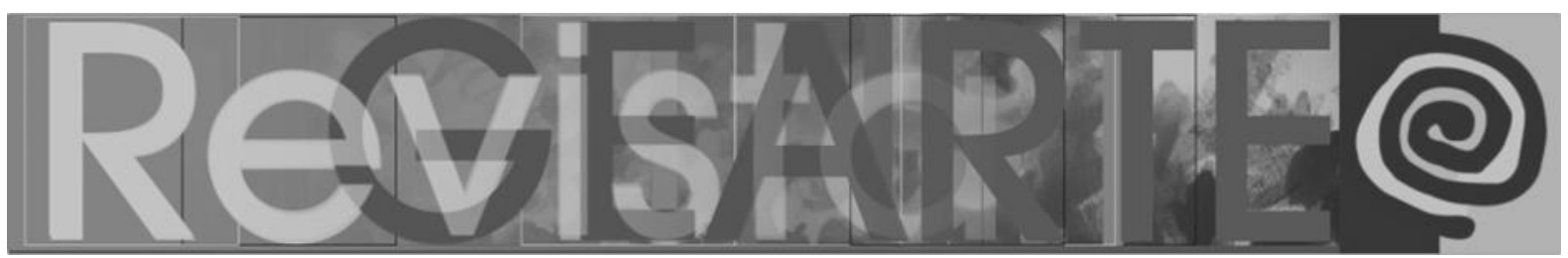

\begin{abstract}
(...)
Baseio meu método - disse-nos - na inclinação de cada um, procurando realizar um trabalho coletivo.

A certeza de que a inspiração é natural e espontânea comprovou-a em demoradas observações. Dessa certeza chegou a outra, não menos importante, de que a técnica é instintiva e que as crianças, após seis meses, podem fazer trabalhos tão perfeitos quanto os de um pintor de muitos anos de prática.

O preconceito de que a técnica somente se adquire depois de muitos anos já não o tem essa artista: a técnica - afirmou-nos - é instintiva. Todo o indivíduo pode desenhar, desde que tenha inteligência normal"7.
\end{abstract}

Mário de Andrade visitou também a exposição dos alunos de Anita e escreveu um artigo no Diário Nacional em novembro de 1930. Além de elogiar os resultados do trabalho da amiga e também da Escola Americana por acreditar no potencial da professora/artista, pelo desenvolvimento da "imaginação criadora" de seus alunos, Mário de Andrade se deteve a explicar, à sua maneira, o que entendeu sobre a questão da técnica no trabalho desenvolvido por Anita com as crianças. Num primeiro comentário, quando falava sobre o perigo de certos trabalhos serem copiados, ele reconheceu que a "insuficiência de habilidade técnica" das crianças poderia aumentar a "aparência de invenção" do trabalho infantil. E mais adiante observou concordando com a professora que "... a criança possui por instinto todos os princípios básicos da técnica de pintura. Chegando mesmo a, dentro das normas gerais da técnica, inventar sua técnica particular" (ANDRADE, 1976, p. 278). E podemos nos perguntar: qual o conceito de técnica que norteava essa observação? Quando Anita se refere a uma "técnica particular", estaria se referindo ao que hoje nomeamos como a "poética" do sujeito?

São muitas as questões que podem saltar dos documentos históricos. E como Anita almejava escrever um livro ilustrado sobre seu método original, projeto que não chegou a realizar, no material deixado por ela datilografado, após o plano de curso, segue algumas observações gerais para os professores e em seguida algumas indicações sobre como trabalhar os elementos de perspectiva, as noções de construção e os elementos de sombra. À guisa de conclusão deste ensaio,

Idem. 


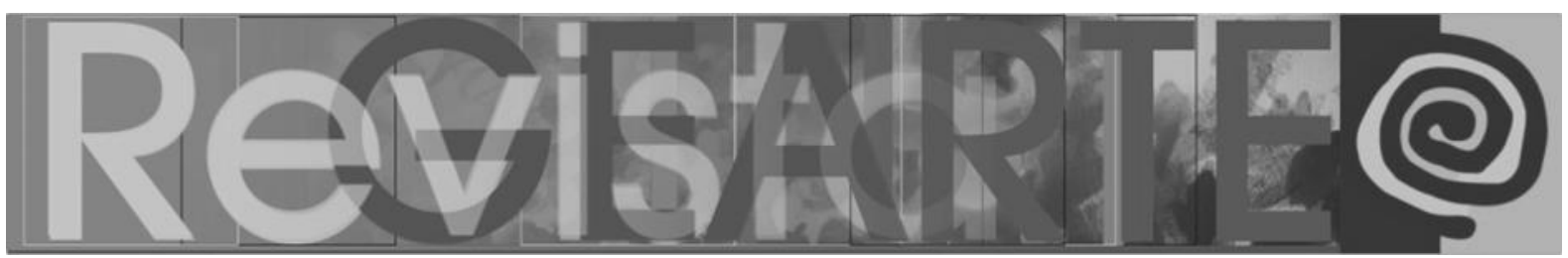

transcrevemos, aqui, as recomendações de Anita na íntegra para que, quiçá, possam gerar outros questionamentos e impulsionar reflexões em direção a outros processos de ensino de desenho para crianças e jovens; ensino que hoje tanta falta tem feito nas salas de aula Brasil afora!

\section{Observações Gerais}

O aluno deverá seguir as seguintes regras:

1. Posição correta do lápis.

2. Não dar voltas ao caderno, mas sim fazer ele as voltas.

O professor seguirá as regras seguintes:

1. Tornar mais possível interessante a classe de desenho.

2. No desenho natural, fazer antes que a classe comece a desenhar, uma análise completa do modelo.

3. Tomar cuidado em fazer notar aos alunos que estando todos copiando de um só modelo, e sendo eles muitos e sentados em diferentes pontos da sala, não poderão todos ver o modelo do mesmo modo.

4. Chamar desde logo a atenção dos alunos para a perfeição das linhas retas ou curvas.

5. Ver que os alunos conservem a boa posição do lápis para evitar os traços muito fortes.

6. Evitar na medida do possível o uso da borracha.

7. Do $\vee$ ano em diante o professor dará aos alunos noções práticas de perspectiva.

\section{Elementos de Perspectiva}

\section{Definição}

Desenhar em perspectiva é desenhar os objetos tais quais são. Considera-se o objeto visto por um só olho.

Prova ilustrativa: com um giz desenhe-se numa vidraça a paisagem vista. Escolhase de preferência uma casa perto ou uma avenida de árvores. No caso de um edifício, far-se-á ver ao aluno que as paralelas situadas num plano inclinado ao raio 


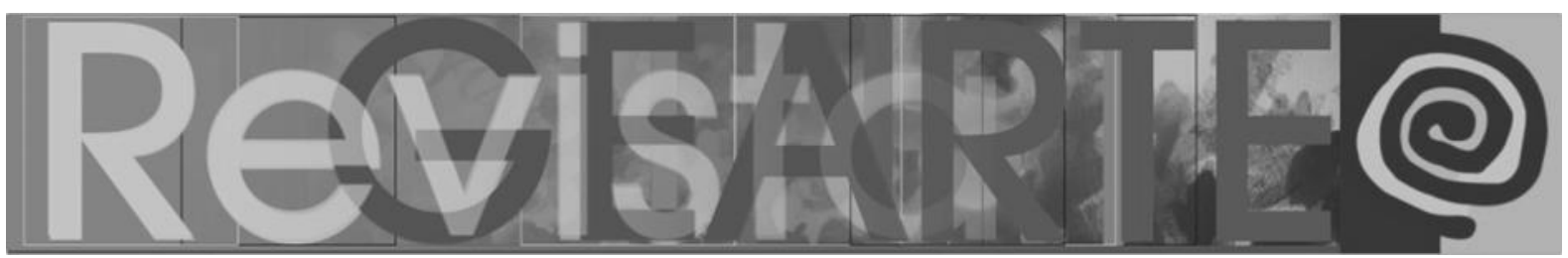

visual não são paralelas na vidraça. Mostre-se que numa avenida de árvores, as árvores apesar de terem a mesma altura, representadas no papel ou na vidraça as mais distantes são as menores. Faça-se notar que as paralelas vão se encontrar em dois pontos, $\mathrm{A}$ e $\mathrm{B}$, que estão no horizonte.

Sem dar a prova geométrica deste fato, faça-se desenhar caixões de madeira grandes (...) e tomando cuidado não apresentar superfícies aos desenhadores, mas sim as arestas, mostre-se que as arestas paralelas vão dar no horizonte em dois pontos.

Definição. Horizonte é o plano horizontal que está na altura do olho do desenhista. Faça-se notar que para cada observador há um horizonte diferente do dos demais observadores.

Consequentemente um aglomerado de cubos, prismas etc. desenhados por uma só pessoa tem um só horizonte, portanto todas as retas dos diversos sólidos do quadro devem se encontrar no mesmo horizonte.

Façam-se desenhos rigorosos no quadro negro para salientar este fato:

Horizonte

\begin{tabular}{l}
$\frac{1^{\circ} \text { caso, horizonte no meio }}{\text { do objeto }}$ \\
$2^{\circ}$ caso, o objeto acima \\
do horizonte ----- - \\
\hline $3^{\circ}$ caso, objeto abaixo \\
do horizonte.
\end{tabular}

Em seguida faça-se desenhar os mesmos de um modelo e corrija-se segundo a lei. Pratique o aluno em achar o horizonte no modelo. Façam-se amontoados de caixões para modelos. Após o aluno tiver desenhado, verifique se as retas vão dar nos dois pontos.

Nota

É sempre conveniente dar modelos bem grandes para facilitar aos desenhistas reproduzir com facilidade a inclinação das arestas. Faça-se notar que um círculo em perspectiva é uma elipse; corrija-se a tendência dos alunos de construir esta elipse pontuada nas extremidades, assim:

Deve ser assim

[Aqui há um espaço em branco que indica que ela faria alguma ilustração] 


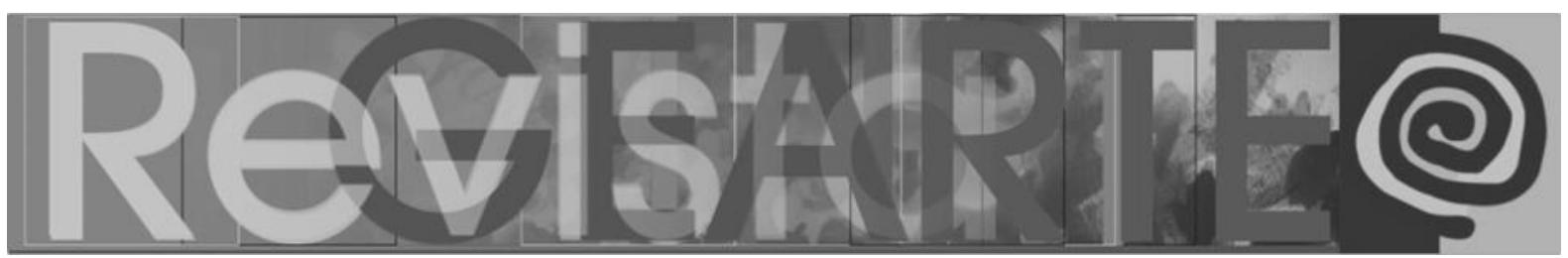

Noções de construção

Quando se vai copiar um modelo, começa-se por estabelecer as relações que existem entre os diversos tamanhos. Isto consegue-se do seguinte modo - por exemplo, desenhar um retângulo: fecha-se um olho, estende-se o braço que segura o lápis, mede-se uma das distâncias, da extremidade do lápis sobre a outra extremidade e compara-se assim seus tamanhos a olho. Por exemplo, pode ser duas vezes mais comprida que larga, etc. ou ainda, a largura pode ser um pouco mais da metade do comprimento, etc. Faça o aluno praticar com diversos modelos irregulares, ex. vasos, objetos da escola, etc.

Em modelos mais complexos faça o aluno construir um esquema antes de desenhar colocando os tamanhos relativos e as posições relativas, ex:

\section{Elementos de Sombra}

Nas diferentes classes não temos que ensinar sombra produzida pelos objetos, mas sim, sombra da luz sobre os objetos.

Vê-se logo que depende da posição em que está colocado o objeto. A face do objeto que fica exposta à luz, levará pouco ou nenhuma sombra, e a parte que não recebe luz, essa então levará a sombra. Nas classes mais atrasadas aconselha-se usar em vez da própria sombra ou traço de sombra que vem a ser os traços do lado não exposto à luz, mais forte do que os outros.

Na sombra, nada mais há que copiar, pois a sombra está no modelo tanto quanto os traços. Quando não se tem modelo, pode-se imaginar os raios de luz partindo de um ponto dado qualquer.

Quanto a posição do lápis nada mais há a observar do que a posição usada na caligrafia, sem segurar com força; antes bem frouxamente o movimento dos dedos é aconselhado.

\section{Referências}

ANDRADE, Mário de. Crônica de arte. Revista do Brasil, n. 86, p. 137-140, fev. 1923.

ANDRADE, Mário de. Mário de Andrade, cartas a Anita Malfatti. Organização de Marta Rossetti Batista. Rio de Janeiro: Forense Universitária, 1989.

ANDRADE, Mário de. Pintura infantil. In: Táxi e crônicas no Diário Nacional. Estabelecimento de texto, introdução e notas de Telê Porto Ancona Lopez. São Paulo: Duas Cidades; Secretaria da Cultura, Ciência e Tecnologia, 1976. p. 277-279.

AZEVEDO, Fernando. A arte como instrumento de educação popular na reforma. In: Novos Caminhos e novos fins. A política de educação no Brasil. (Obras completas, v. VII). São Paulo: Melhoramentos, 1958. p. 117-131. 


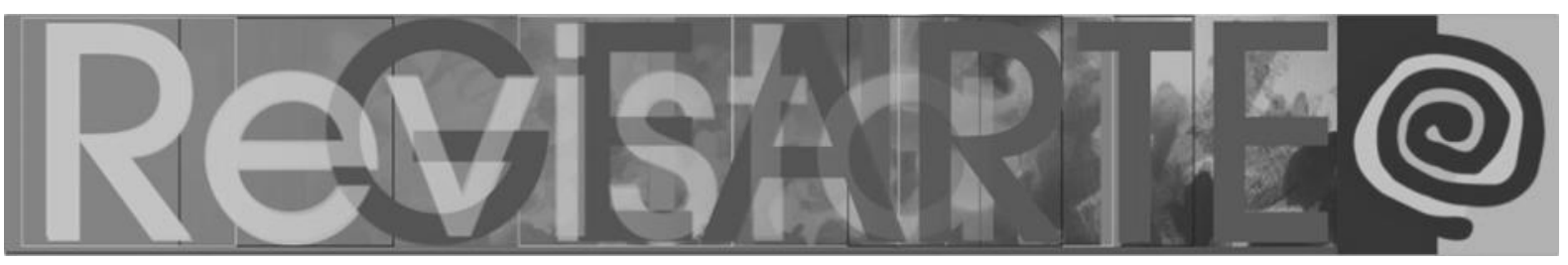

BARBOSA, Ana Mae. Arte-educação no Brasil: das origens ao modernismo. São Paulo: Perspectiva, 1978.

BARBOSA, Ana Mae. Recorte e colagem: influência de John Dewey no ensino da arte no Brasil. São Paulo: Cortez, 1982.

BARBOSA, Ana Mae. Tópicos utópicos. Belo Horizonte: C/Arte, 1998.

BARBOSA, Ana Mae (Org.) Ensino da arte: memória e história. São Paulo: Perspectiva, 2008.

BATISTA, Marta Rossetti. Introdução. In: Mário de Andrade, cartas a Anita Malfatti. Organização de Marta Rossetti Batista. Rio de Janeiro: Forense Universitária, 1989. p. 13-45.

BATISTA, Marta Rossetti. Anita Malfatti no tempo e espaço: biografia e estudo da obra. São Paulo: Ed. 34; Edusp, 2006.

CARVALHO, Cibele Regina de. Um estudo sobre a docência na vida e na carreira de Anita Malfatti. 2007. Dissertação (Mestrado em Educação, Arte e História) - Universidade Presbiteriana Mackenzie, São Paulo.

COUTINHO, Rejane Galvão. A coleção de desenhos infantis do acervo Mário de Andrade. 2002. Tese (Doutorado em Artes) - ECA/USP, São Paulo.

COUTINHO, Rejane Galvão. Mário de Andrade e os desenhos infantis. In: Ana Mae Barbosa (Org.). Ensino da arte: memória e história. São Paulo: Perspectiva, 2008. p. 157-195.

COUTINHO, Rejane Galvão. Mário de Andrade como gestor cultural: ações arte/educativas voltadas para crianças na cidade de São Paulo. In: CONGRESSO NACIONAL DA FEDERAÇÃO DE ARTE/EDUCADORES DO BRASIL, 26., 2016, Boa Vista. Anais... Boa Vista: FAEB/UFRR, 2016. p. 228-244.

COUTINHO, Rejane Galvão. Mário de Andrade, a educação estética e a mediação cultural. In: ENCONTRO DA ASSOCIAÇÃO NACIONAL DE PESQUISADORES EM ARTES PLÁSTICAS: MEMÓRIAS E INVENTAÇÕES, 26., 2017, Campinas. Anais... Campinas: ANPAP, PUC, 2017. p. 2397-2408.

COUTINHO, Rejane Galvão. O Desenho na História: uma interpretação. In: CONGRESSO NACIONAL DA FEDERAÇÃO DE ARTE/EDUCADORES DO BRASIL, 27., 2017, Campo Grande/MS. Anais... Campo Grande: FAEB/UFMS, 2017. p. 190-202.

LUQUET, George-Henri. Le dessin enfantin. Paris: Felix Alcan, 1927.

O LABORATORIO de Pedagogia Experimental. Escola Normal Secundaria de São Paulo. São Paulo: Siqueira, Nagel \& Comp., 1914.

RABELLO, Sylvio. Psicologia do desenho infantil. São Paulo: Companhia Editora Nacional, 1935.

ROUMA, Georges. Le langage graphique de l'enfant. Paris: Misch \& Thorn, 1913.

WILSON, Brent; HURWITZ, Al; WILSON, Marjorie. Teaching drawing from art. Worcester, Massachusetts: Davis Publications, 1987. 


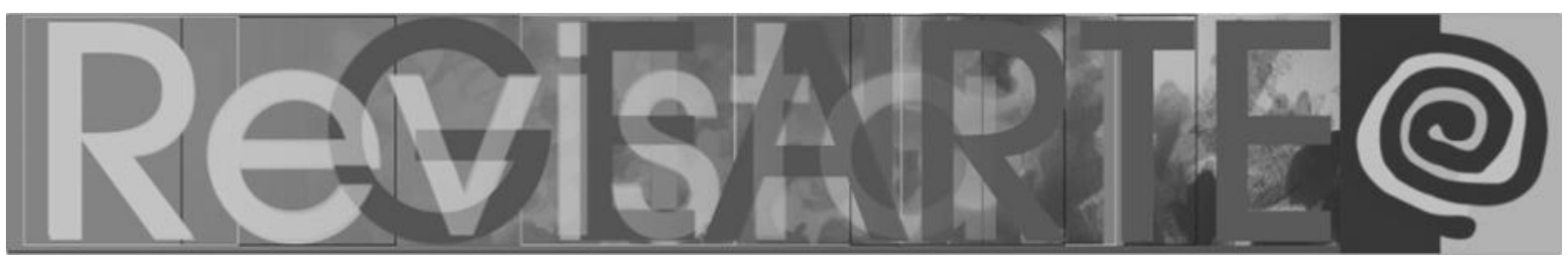

\section{Rejane Galvão Coutinho}

Graduada em Educação Artística pela Universidade Federal de Pernambuco (1988), mestrado (1998) e doutorado (2002) em Artes pela Universidade de São Paulo, Pós-doutorado pela Universidade Pública de Navarra, Espanha (2011/2012). É professora do Instituto de Artes da Universidade Estadual Paulista, UNESP, onde atua na Licenciatura em Artes Visuais e na PósGraduação em Artes, área de Arte e Educação. Coordenadora do Mestrado Profissional em Artes, Prof-Artes, do Instituto de Artes da UNESP. Tem desenvolvido pesquisas com foco na história do ensino de artes e na formação de arte/educadores e mediadores culturais.

ORCID: http://orcid.org/0000-0002-9761-8135

E-mail: rejanegcoutinho@gmail.com

Currículo: http://lattes.cnpq.br/9150659098334633

Recebido em 7 de setembro de 2019 Aceito em 9 de dezembro de 2019 